\title{
Where to see climate change best in radio occultation variables - study using GCMs and ECMWF reanalyses
}

\author{
B. C. Lackner, A. K. Steiner, and G. Kirchengast \\ Wegener Center for Climate and Global Change (WEGC) and Institute for Geophysics, Astrophysics, and Meteorology/Inst. \\ of Physics (IGAM/IP), University of Graz, Graz, Austria
}

Received: 12 August 2011 - Revised: 31 October 2011 - Accepted: 4 November 2011 - Published: 29 November 2011

\begin{abstract}
Radio occultation (RO) is a new technique to observe the upper troposphere and lower stratosphere (UTLS), a region that reacts particularly sensitive to climate change. Featuring characteristics such as long-term stability, SI traceability, all-weather capability, global coverage, and high accuracy and vertical resolution, RO data fulfill the requirements for climate monitoring in the UTLS. However, while a range of studies has shown the climate utility of RO it has not yet been explored sytematically where to see climate change best in RO variables. Therefore we perform here a systematic trend study for the RO variables refractivity, pressure, and temperature (bending angle, not depending on height but impact parameter, is left for separate study). The trends, given at geopotential height levels and for layer gradients, are explored to determine seasons, geographic regions, and height domains, which show a significant trend signal. Because continuous RO data are available since 2001 only, reanalyses (ERA-40 and ERA-Interim) and global circulation model simulations of the Intergovernmental Panel on Climate Change Assessment Report 4 (CCSM3, ECHAM5, HadCM3) are used as proxy data for RO. It is shown that $\mathrm{RO}$ data are sensitive at different height ranges and that thus several indicators of climate change can be retrieved. Refractivity emerges as indicator in the lower stratosphere (LS) and tropopause region at about $14 \mathrm{~km}$ to $24 \mathrm{~km}$, pressure over the whole UTLS, and both in all large-scale regions except the polar caps. Temperature qualifies as indicator in the upper troposphere below about $16 \mathrm{~km}$ and in the LS above about $21 \mathrm{~km}$. Overall, refractivity and pressure alone are adequate indicators for the UTLS, but temperature as commonly used variable facilitates easy interpretation of results. Layer gradients were found to be further sensitive indicators providing additional information. Besides large-scale global and hemi-
\end{abstract}

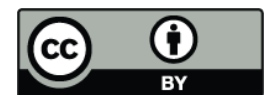

Correspondence to: B. C. Lackner (bettina.lackner@uni-graz.at) spheric means the tropics and the mid-latitudes appear as regions suitable to track climate change with RO data. The results also point to the value of utilizing in addition to annual means specific seasons, such as northern hemispheric fall and summer, for early climate signal detection. Since RO data feature much better vertical resolution than the proxy data of this study, more detailed insights can be expected when a longer $\mathrm{RO}$ record will be available.

Keywords. Atmospheric composition and structure (Pressure, density, and temperature) - Meteorology and atmospheric dynamics (Climatology) - Radio science (Remote sensing)

\section{Introduction}

Noticeable changes in our climate system are not limited to the Earth's surface, but emerge as well very clearly in the upper troposphere and lower stratosphere (UTLS), where the vertical thermal structure reflects a balance between radiative, convective, and dynamical heating and cooling processes (Andrews et al., 1987; Holton, 2004). Upper air observations are available since the establishment of radiosondes in the late 1950s and the implementation of spaceborne measurement systems in the late 1970s (Karl et al., 2006). These systems were not intended for climate monitoring and thus show shortcomings in this respect as discussed, e.g. by Santer et al. (2008) or Randel et al. (2009). Nevertheless, they are widely used in climate research due to the absence of a specific upper air climate monitoring record. A data record suitable for atmospheric climate monitoring has to supply vertically well resolved, accurate, long-term stable and consistent data, which depict the mean state and the variability of the atmosphere with an accuracy better than the expected long-term changes.

Published by Copernicus Publications on behalf of the European Geosciences Union. 
For the UTLS ( $\approx 5 \mathrm{~km}$ to $35 \mathrm{~km}$ ), these climate data qualities can be provided by measurements of the Global Navigation Satellite System (GNSS) radio occultation (RO) technique (e.g. Foelsche et al., 2009; Anthes, 2011). GNSS signals, e.g. from the US Global Positioning System (GPS), are used to scan the atmosphere near-vertically from top to bottom or vice versa due to the relative motion between a GPS satellite (transmitter) and a low earth orbit (LEO) satellite (receiver). The radio signals pass across the atmosphere and are refracted by the Earth's refractivity (density) field. Detailed descriptions of the RO method are given by, e.g. Kursinski et al. (1997) or Hajj et al. (2002). Measurements of excess phases during an occultation event are based on timing with precise atomic clocks. This enables selfcalibration and long-term stability of RO measurements (Ho et al., 2009). Near polar orbits ensure global coverage with already single-satellite measurements (Pirscher et al., 2007). All weather capability in the vertical regions considered here is provided since the radio signals $(19 \mathrm{~cm}$ and $24 \mathrm{~cm}$ wavelengths) are essentially insensitive to clouds. RO data from different satellites can be combined with no need of intercalibration or temporal overlapping as long as the same processing system is used (Hajj et al., 2004; Foelsche et al., 2011). Retrieved atmospheric variables from RO include bending angle, refractivity, pressure, geopotential height, temperature, and lower-to-mid tropospheric water vapor.

The potential of RO data to track climate change has already been demonstrated in a range of studies; Steiner et al. (2011) provided a recent review on the work so far. For brevity, we more specifically point only to a few here, which we see as particular forerunners to this systematic, multidecadal study. Leroy (1997) discussed the use of geopotential height fields (summer season only) at constant pressure levels, which correspond to tropospheric bulk temperature. Vedel and Stendel (2003) investigated the capability of geopotential height, pressure, and refractivity to assess climate change. In the lower stratosphere (LS), they proposed to use geopotential height at iso-refractivity layers, which is found slightly more sensitive to global warming than using pressure-dependent variables.

Leroy et al. (2006) proposed to use refractivity preferably as function of geopotential height, arguing that this is the more natural independent vertical coordinate. Dry pressure is mentioned as well suited for climate monitoring above the lower troposphere, where the water vapour contribution to refractivity is negligible (log-dry pressure trends are then similar to geopotential height trends). Using an optimal detection approach, they estimated the time required to detect a significant trend signal (hereinafter referred to as detection time) in log-dry pressure to be 6 to 13 years ( $95 \%$ confidence level).

Ringer and Healy (2008) focused on assessing the monitoring utility of bending angles and found for simulated UTLS data detection time estimates of 10 to 16 years. These detection time estimates where found confirmed using real RO data by Lackner et al. (2011). The trend detection ca- pability of different RO variables for summer season was analysed by Foelsche et al. (2008b), performing an observing system simulation experiments over a 25 -year period. They concluded that the RO variables show complementary climate change sensitivity in different regions of the UTLS.

Tropopause heights retrieved from RO bending angle climatologies were recently discussed by Schmidt et al. (2010). They point out the excellence of RO data for climate monitoring of the tropopause (TP) due to its good vertical resolution. The paper also showed that temperature is needed in addition to bending angles to ease the interpretation of tropopause height changes.

None of these studies so far has explored systematically the long-term climate monitoring utility of the data over different variables, seasons, regions, and height ranges, however. Therefore, this study systematically assesses the multidecadal UTLS climate monitoring potential of the RO variables refractivity, pressure, and temperature, depending on season, region, and height domain (bending angle, not depending on height but impact parameter, is left for separate study). The analysis is based on fields given at geopotential height levels. The influence of the choice of the vertical coordinate on trends is addressed. The goal is to deduce the most promising indicators in space and time. We use the term indicator to pinpoint $\mathrm{RO}$ variables in regions, which react particularly sensitive to climate change relative to natural variability, implying a high signal-to-noise ratio (SNR). Due to the still limited length of continuous RO data (starting in fall 2001), we use reanalyses and fields from global circulation models (GCMs) as proxy for RO.

Data and study design are introduced in Sect. 2. Results of the trend study are presented in Sect. 3 and discussed in Sect. 4 with respect to RO climatologies. We close with a summary and conclusions in Sect. 5.

\section{Data and method}

\subsection{Radio occultation data and RO-accessible variables}

Besides intermittent RO measurements by the GPS/Met (GPS Meteorology) proof-of-concept mission within 1995 to 1997 (e.g. Ware et al., 1996; Rocken et al., 1997; Steiner et al., 1999), continuous RO measurements are available since mid 2001 from various satellite missions. At present, the longest record is provided by the CHAMP (Challenging Mini-Satellite Payload) satellite (Wickert et al., 2001, 2004). From September 2001 to September 2008, CHAMP delivered around 140 to 180 occultation events per day of sufficient quality to pass quality control during the retrieval of atmospheric profiles. Further satellite missions are GRACE (Gravity Recovery and Climate Experiment; e.g. Beyerle et al., 2005; Wickert et al., 2005), and Formosat3/COSMIC; the latter comprises six satellites which provide up to about 2000 quality occultation events per day (e.g. 
Anthes et al., 2008). RO observations are ensured at least until the year 2020 with the MetOp series of three satellites launched in sequence to operate at least 14 years from 2006 onwards (e.g. Loiselet et al., 2000; Luntama et al., 2008). Additional future missions, including also plans for multisatellite constellations (see, e.g. Anthes, 2011), will enable the continuation of long-term monitoring of the UTLS at a higher horizontal resolution. RO measurements allow the retrieval of profiles of atmospheric variables, from bending angle $\alpha$, refractivity $N$, geopotential height $Z$, and pressure $p$ to air temperature $T$. Separation of specific humidity and temperature in the lower-to-middle troposphere requires background information over the troposphere (e.g. short-range forecast data from numerical weather prediction, Healy and Eyre, 2000; Kursinski and Hajj, 2001), to resolve the wetdry ambiguity inherent in refractivity. The Smith-Weintraub formula (Smith and Weintraub, 1953) used to express microwave refractivity reads

$N \equiv(n-1) 10^{6}=k_{1} \frac{p}{T}+k_{2} \frac{p_{\mathrm{w}}}{T^{2}}$,

where $n$ is the refractive index, $p_{\mathrm{w}}$ the partial pressure of water vapour, $k_{1}=77.6 \mathrm{~K} \mathrm{hPa}^{-1}$, and $k_{2}=3.73 \times$ $10^{5} \mathrm{~K}^{2} \mathrm{hPa}^{-1}$. If atmospheric humidity is small (valid for the UTLS above $5 \mathrm{~km}$ to $8 \mathrm{~km}$ ), the second right-hand side term in Eq. (1) can be disregarded, leading to dry pressure and dry temperature as provided by the current Wegener Center RO processing scheme (e.g. Pirscher, 2010). Since dry temperature is always lower than physical temperature if water vapour is present (e.g. Scherllin-Pirscher et al., 2011), dry temperature trends associated with warming cannot exceed physical temperature trends (Steiner et al., 2009) and are in this sense always conservative. Dry temperature trends exceeding physical ones would only occur if there was a decrease in absolute humidity, which is unlikely when the climate warms (Held and Soden, 2006). Based on profiles from a single satellite, global monthly mean zonal mean climatologies with a latitudinal resolution of $5^{\circ}$ and a vertical resolution of about $1 \mathrm{~km}$ in the UTLS can be calculated. Climatologies with higher horizontal resolutions can be provided when more measurements are available from multi-satellites, such as Formosat-3/COSMIC.

For climate monitoring, complete error characteristics of the data as well as estimates of structural uncertainty are important. Both can be specified for RO data. The sampling error (SE) gives an estimate for uncertainty in monthly mean RO climatologies due to uneven sampling in space and time. It is generally smaller at low latitudes, where there is less atmospheric variability within a month. Details and robust estimation of the SE and the relevance and utility of subtracting it from RO climatologies are discussed by Scherllin-Pirscher et al. (2011). For single-satellite climatologies, the SE is $<0.3 \mathrm{~K}$ in the UTLS, becoming smaller when more satellites are used (Foelsche et al., 2009). Removing of the SE from RO climatologies leads to residual SEs of $<0.1 \mathrm{~K}$ for ver- tically resolved data at low and middle latitudes (ScherllinPirscher et al., 2011), so that the incomplete spatio-temporal sampling would have only a marginal effect on trend estimates.

To illustrate this, Fig. 1 shows trends of RO for the 2001 to 2010 period and the influence of the SE removal on the trends (for the method of trend calculation, see Sect. 2.4). In those regions, where the trends are pronounced (and potentially significant), SE removal changes the trends only slightly, in most cases less than $10 \%$. Only where trends are small, the SE influence on the trends can be of the same order of magnitude as the trends themselves. In any case, SE removal leads to generally improved climatological fields, confirmed with structural uncertainty estimates.

Such structural uncertainty, defined as unintentional bias arising from the chosen methodological approaches (Thorne et al., 2005), was estimated by Ho et al. (2009) for RO refractivity climatologies from four processing centers (including the Wegener Center). They estimated the uncertainty in trends with $\pm 0.04 \%$ per 5 years and between $-0.03 \%$ and $0.01 \%$ per 5 years after removing the SE from the data. In summary, these favourable error characteristics of RO data underpin their utility to monitor long-term trends. They furthermore justify and strongly motivate the broader multi-decadal outlook of this study to explore systematically, where RO data will see trends best and most robustly.

We analyse the three main atmospheric variables, which are accessible by the RO method (refractivity, pressure, and temperature as function of geopotential height), and three derived variables (relative refractivity gradients, relative pressure gradients, and temperature gradients across three selected height layers; for details about the levels and layers see Sect. 2.3). These variables can also be easily derived from climate model output. The data are used at geopotential height levels (above mean sea level (MSL), like MSL altitude), as this vertical coordinate is invariant to climate change and the coordinate selection does indeed matter. To illustrate this, Fig. 2 shows relative trend patterns for the RO variables as function of pressure and MSL altitudes based on ERA-Interim data (see Sect. 2.2). While the humidity, temperature and geopotential height/pressure trends are almost independent of the vertical coordinate, this is not the case for refractivity. This can be explained by inspecting the total derivative of the Smith-Weintraub formula for the dry air first right-hand-side term in Eq. (1),

$\frac{\partial N}{\partial t} \propto \frac{1}{T} \frac{\partial p}{\partial t}-\frac{p}{T^{2}} \frac{\partial T}{\partial t} \Rightarrow \frac{1}{N} \frac{\partial N}{\partial t} \propto \frac{1}{p} \frac{\partial p}{\partial t}-\frac{1}{T} \frac{\partial T}{\partial t}$,

which shows that the relative change in refractivity appears to be a difference between the relative changes in pressure and temperature. If pressure is considered as constant (when using data at constant pressure levels), relative refractivity changes (Fig. 2a) are proportional (with opposite sign) to relative temperature changes (Fig. 2e). This is not the case if refractivity is analysed at vertical levels invariant to climate 

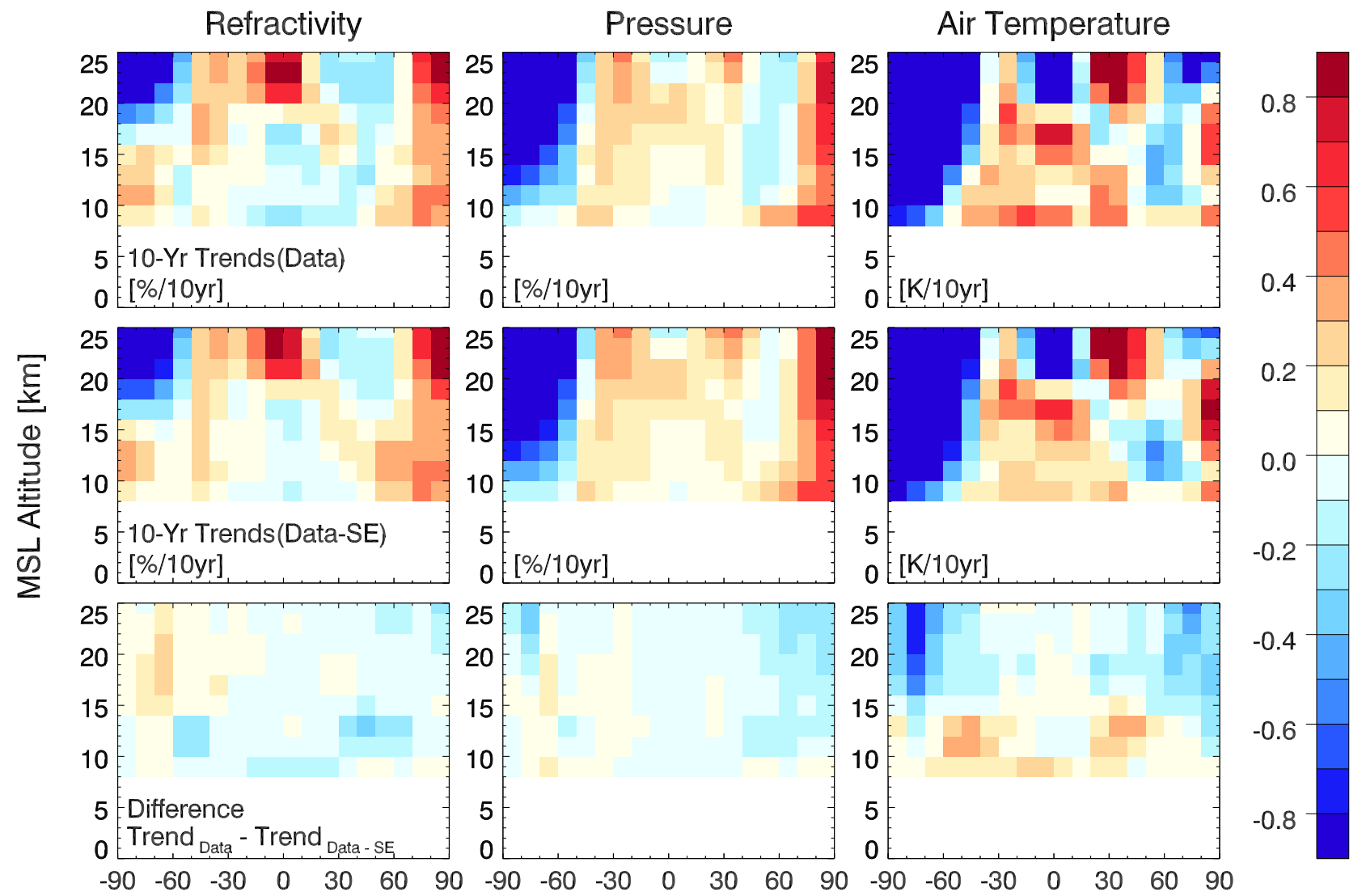

\section{Latitude [deg]}

Fig. 1. RO multi-satellite (CHAMP, Formosat-3/COSMIC satellites 1-6, GRACE-A) trend patterns for relative refractivity (left), relative pressure (middle), and temperature (right). Depicted are in the top row 10-year trends based on the period September 2001 to July 2010 (Wegener Center OPSv5.4 data; Steiner et al., 2009; Pirscher, 2010). The trends originate from time-series of monthly mean RO anomalies (from each month the mean of all respective months was subtracted). Middle row shows same format as top, but based on anomalies from which the sampling error was removed before calculating the trends. Bottom row depicts the influence of removing the sampling error from data when calculating the trends (i.e. difference of top and middle).

change (altitude or geopotential height above MSL), since then refractivity (Fig. 2b) shows a combined dry temperature and pressure signal (Fig. 2d, f). Geopotential height is thus selected as the most suitable coordinate for inspecting trends in this study. Some results on pressure levels have been presented by Lackner et al. (2009) and Lackner (2010).

\subsection{Data sets for trend analysis}

Since the available RO record is still too short for multidecadal climate change studies, we use reanalyses and selected GCMs as proxy for RO. As "observational" data set we employ the ECMWF ERA-40 (Simmons and Gibson, 2000; Uppala et al., 2005) and ERA-Interim (ERA-INT, Simmons et al., 2007a,b; Uppala et al., 2008) reanalyses. They feature a continuous spatial and temporal coverage, which is generally not provided by single observational data records.
Reichler and Kim (2008) analysed uncertainties in the climate mean state of several data sets sets (not including RO) and concluded that ERA-40 matches best the observations. Employing both, ERA-40 and ERA-INT, provides on the one hand an insight in trends of the two reanalyses and on the other hand an insight in the development of trends in two different periods, which are separated by about 10 years. Since reanalyses are more reliable after 1979 when satellite data were included, we only use ERA-40 data of the satellite era 1980 to 2001 (Uppala et al., 2005; Kehrer et al., 2008). ERAINT is used over 1989 to 2005 , the end chosen so that trends do not span 2006 and beyond. The reason for this is that since end of 2006 a large number of RO data (from Formosat3/COSMIC) are assimilated and impact UTLS temperature by up to $0.2 \mathrm{~K}$ (for details on this 2006 inhomogeneity see Poli et al., 2010). 


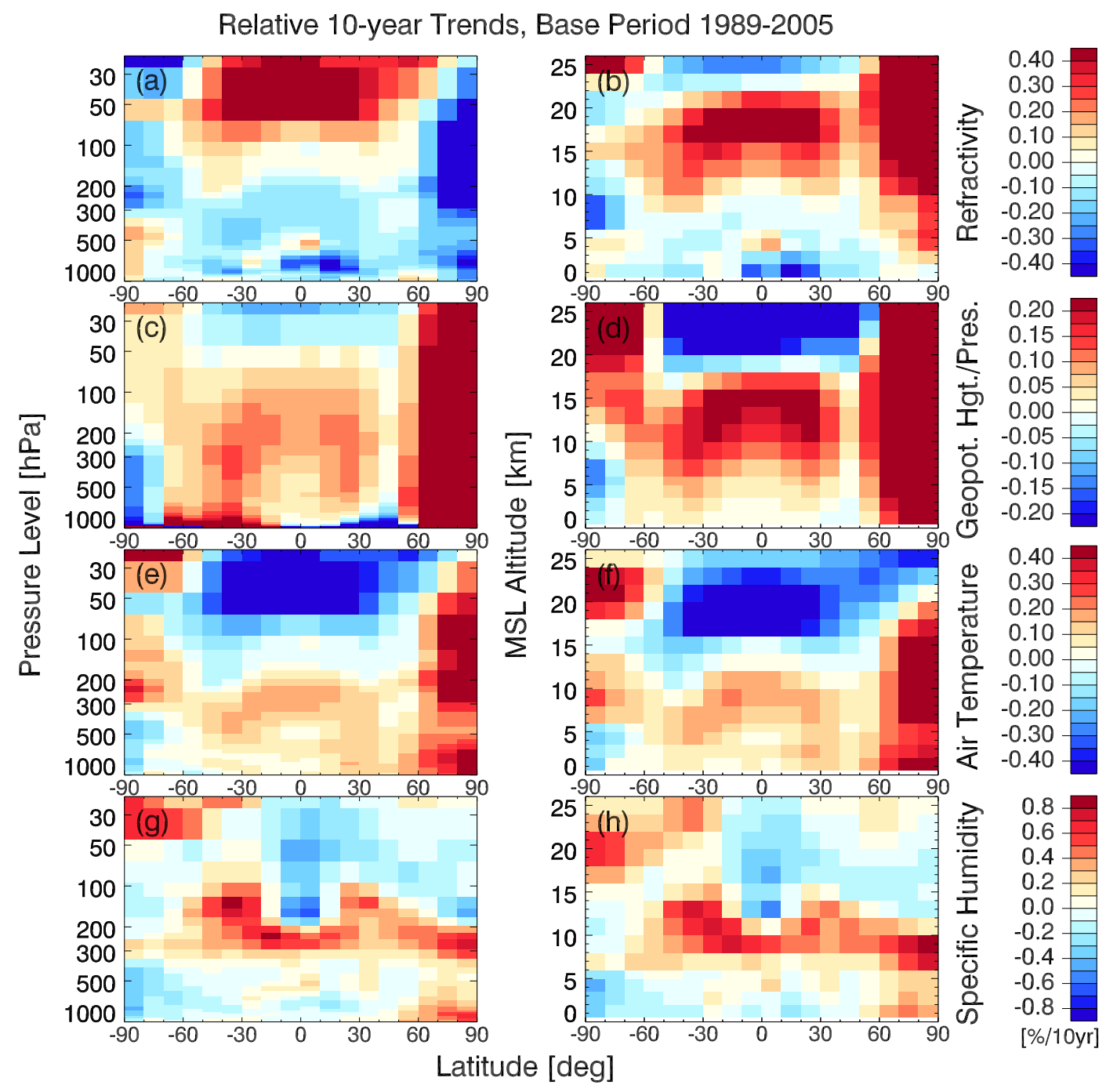

Fig. 2. Decadal trends of ERA-INT (base period 1989 to 2005). Shown are relative trend patterns for refractivity (a-b), geopotential height at pressure levels (c) and pressure at MSL altitudes (d), temperature (e-f), and specific humidity (g-h). The left column shows patterns as function of constant pressure levels, the right column as function of MSL altitude.

To estimate even long-term trends, we employ A2 and B1 21st century scenario simulations (Nakićenović et al., 2000) of three representative GCMs of the Intergovernmental Panel on Climate Change (IPCC) Fourth Assessment Report (AR4): CCSM3 from the National Centers for Environmental Prediction and the National Center for Atmospheric Research (5/7 simulations of A2/B1 scenarios and respective 20th century runs for comparisons with the reanalyses; Collins et al., 2006); ECHAM5 from the MaxPlanck-Institute for Meteorology in Hamburg (3/3 simulations of $\mathrm{A} 2 / \mathrm{B} 1$ and 20th century scenario; Roeckner et al., 2003); HadCM3 from the Hadley Centre for Climate Prediction and Research of the UK MetOffice (1/1 simulation of A2/B1 and 20th century scenario; Gordon et al., 2000; Pope et al., 2000). The data were downloaded from the WCRP CMIP3 (World Climate Research Programme's Work- ing Group on Coupled Modelling) multi-model database (esg.llnl.gov:8080/home/publicHomePage.do, 02/2008).

According to an analysis of Reichler and Kim (2008), the selected models show good agreement with observations in their time-mean state of the climate and belong to the 5 best performing models without flux-correction (needed by some models to achieve a stable climate). Model results differ depending on the kind of natural and anthropogenic forcings used within the simulations. The selected models all use ozone depletion and recovery forcings in their simulations (J. Meehl, NCAR/USA, T. Johns, MetOffice/UK, J. Gregory, MetOffice/UK, personal communication, December 2007; Roeckner et al., 2005), which plays an essential role for simulating stratospheric temperature fields (Forster et al., 2007). For the 20th century experiments observed greenhouse gas increase was used. For A2 and B1 simulations beyond 1999, 


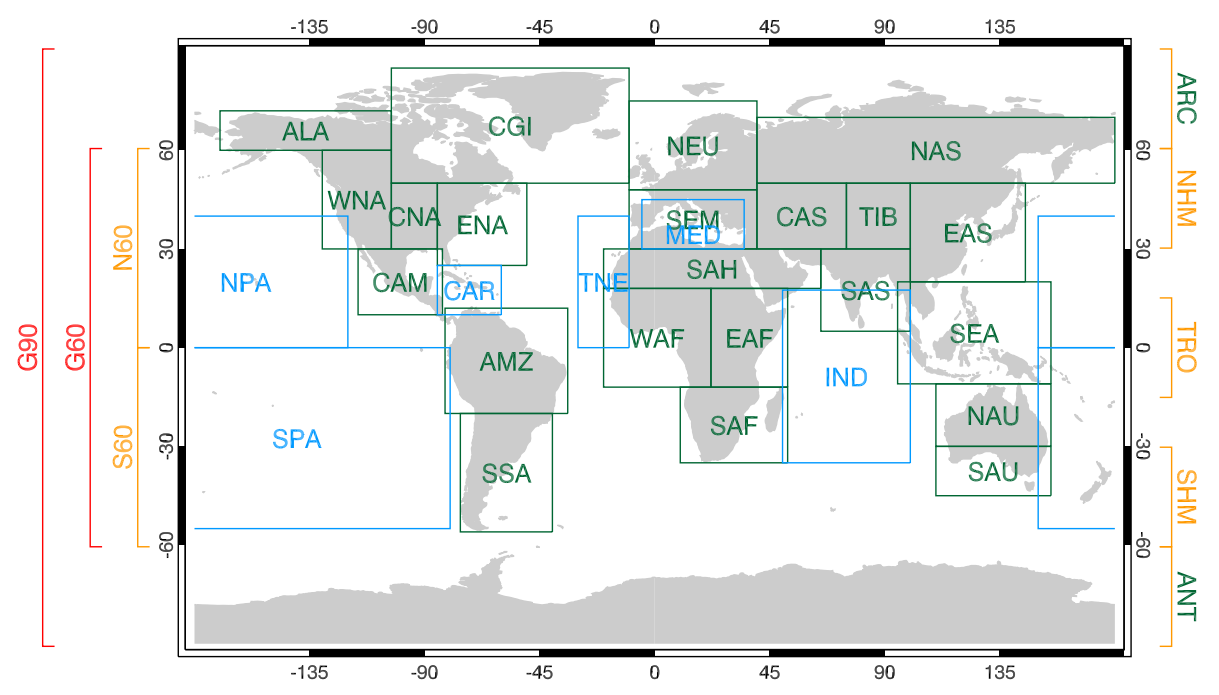

Fig. 3. Large-scale regions over land (green) and oceans (blue) based on the IPPC (2007) definition, complemented by global-scale zonal bands (marked at both sides in orange and red) typical for RO climate studies. The acronyms used for all regions are as well indicated. For details see Table 1.

direct (all GCMs) as well as indirect (HadCM3) or semidirect (CCSM3, ECHAM5) sulfate aerosol forcings were used in addition to greenhouse gas and ozone forcings.

\subsection{Spatio-temporal gridding of the data}

The ERA and GCM data were re-gridded to a common $2.5^{\circ} \times 2.5^{\circ}$ grid in latitude and longitude to comply with the average horizontal resolution of RO events (about $300 \mathrm{~km}$; Kursinski et al., 1997). All fields are originally given at pressure levels and were converted to geopotential height levels. The geopotential heights were chosen to be close to the given pressure levels, using 1976 Standard Atmosphere (National Oceanic Atmospheric Administration et al., 1976) properties. Temperature and pressure were derived directly from the data set, refractivity was calculated following Eq. (1), by expressing the water vapour pressure as function of specific humidity and pressure by standard formulae (e.g. Salby, 2006).

We use 14 geopotential height levels from near surface to the lower stratosphere, namely at $0.5 \mathrm{~km}, 2 \mathrm{~km}, 3.5 \mathrm{~km}, 5 \mathrm{~km}$, $6.5 \mathrm{~km}, 8.5 \mathrm{~km}, 10 \mathrm{~km}, 11.5 \mathrm{~km}, 13.5 \mathrm{~km}, 16 \mathrm{~km}, 18.5 \mathrm{~km}$, $21 \mathrm{~km}, 24.5 \mathrm{~km}$, and $28 \mathrm{~km}$. The focus is on the $8.5 \mathrm{~km}$ $(300 \mathrm{hPa})$ to $28 \mathrm{~km}(20 \mathrm{hPa}) \mathrm{RO}$ domain, which is captured by 9 levels. We show results at the lower levels only for context and completeness. For the gradients, we concentrate on three "layers", specified by a lower and an upper geopotential height level. The layers characterize the upper troposphere (UT; $8.5 \mathrm{~km}$ to $11.5 \mathrm{~km}$ level corresponding to approx. $300 \mathrm{hPa}$ and $200 \mathrm{hPa}$ ), the tropopause region (TP; $11.5 \mathrm{~km}$ to $16.0 \mathrm{~km}$ level corresponding to approx. $200 \mathrm{hPa}$ and $100 \mathrm{hPa}$ ), and the lower stratosphere (LS; $16.0 \mathrm{~km}$ to $24.5 \mathrm{~km}$ level corresponding to approx. $100 \mathrm{hPa}$ and $30 \mathrm{hPa}$ ). The height domain naming was evidently chosen to be ap- proximately in accordance with the typical UT, TP, LS layering at low to mid-latitudes. The temperature gradients, $\Delta T / \Delta Z$, are determined in units $\mathrm{K}$ per $100 \mathrm{~m}$ and are calculated as

$$
\frac{\Delta T}{\Delta Z}(t)=\frac{T_{\text {upper }}(t)-T_{\text {lower }}(t)}{Z_{\text {upper }}(t)-Z_{\text {lower }}(t)} \cdot 100 .
$$

The index "upper" and "lower" indicates the chosen boundary level of the layer. For refractivity and pressure, relative gradients, $\Delta x_{\text {rel }} / \Delta Z$ in units $\%$ per $100 \mathrm{~m}$, are calculated to take the exponential behaviour of these variables with altitude into account,

$$
\frac{\Delta x_{\text {rel }}}{\Delta Z}(t)=\frac{100 \cdot\left(x_{\text {upper }}(t)-x_{\text {lower }}(t)\right) / x_{\text {lower }}(t)}{Z_{\text {upper }}(t)-Z_{\text {lower }}(t)} \cdot 100,
$$

where $x$ stands for refractivity or pressure.

Based on the gridded fields, we calculated area-weighted means for 37 regions (see Fig. 3 and Table 1). The weighting accounts for the latitudinal dependence of the surface area, caused by the spherical shape of the Earth (meridian convergence). The area means were calculated from monthly-mean data at all grid points within each selected region. The 37 regions provide the basis for the trend analysis. The focus regions are 9 large-scale zonal means, as they are typically used in single-satellite RO studies, spanning from global over hemispheric to zonal means of $10^{\circ}$ latitudinal width. As ongoing and future multi-satellite missions will also enable the calculation of regional climatologies, the analysis was also performed for regions as defined in Chapter 11 (Christensen et al., 2007) of the IPCC AR4. This definition includes 22 land regions, 6 oceanic areas, and the 2 polar caps (ARC, ANT), which we carry along with the large-scale zonal mean regions. 
Table 1. Definition of regions used in the study.

\begin{tabular}{|c|c|c|c|}
\hline Abbrev. & Region & Latitude & Longitude \\
\hline \multicolumn{4}{|c|}{ Zonal bands } \\
\hline G90 & Global90 & $90^{\circ} \mathrm{S}-90^{\circ} \mathrm{N}$ & $180^{\circ} \mathrm{W}-180^{\circ} \mathrm{E}$ \\
\hline G60 & Global60 & $60^{\circ} \mathrm{S}-60^{\circ} \mathrm{N}$ & $180^{\circ} \mathrm{W}-180^{\circ} \mathrm{E}$ \\
\hline N60 & Northern60 & $00^{\circ} \mathrm{N}-60^{\circ} \mathrm{N}$ & $180^{\circ} \mathrm{W}-180^{\circ} \mathrm{E}$ \\
\hline S60 & Southern60 & $60^{\circ} \mathrm{S}-00^{\circ} \mathrm{S}$ & $180^{\circ} \mathrm{W}-180^{\circ} \mathrm{E}$ \\
\hline ARC & Arctic & $60^{\circ} \mathrm{N}-90^{\circ} \mathrm{N}$ & $180^{\circ} \mathrm{W}-180^{\circ} \mathrm{E}$ \\
\hline NHM & Northern Hemisphere mid-latitudes & $30^{\circ} \mathrm{N}-60^{\circ} \mathrm{N}$ & $180^{\circ} \mathrm{W}-180^{\circ} \mathrm{E}$ \\
\hline TRO & Tropics & $15^{\circ} \mathrm{S}-15^{\circ} \mathrm{N}$ & $180^{\circ} \mathrm{W}-180^{\circ} \mathrm{E}$ \\
\hline SHM & Southern Hemisphere mid-latitudes & $60^{\circ} \mathrm{S}-30^{\circ} \mathrm{S}$ & $180^{\circ} \mathrm{W}-180^{\circ} \mathrm{E}$ \\
\hline ANT & Antarctic & $90^{\circ} \mathrm{S}-60^{\circ} \mathrm{S}$ & $180^{\circ} \mathrm{W}-180^{\circ} \mathrm{E}$ \\
\hline \multicolumn{4}{|l|}{ America } \\
\hline ALA & Alaska, NW Canada & $60^{\circ} \mathrm{N}-72^{\circ} \mathrm{N}$ & $170^{\circ} \mathrm{W}-103^{\circ} \mathrm{W}$ \\
\hline CGI & East Canada, Greenland and Iceland & $50^{\circ} \mathrm{N}-85^{\circ} \mathrm{N}$ & $103^{\circ} \mathrm{W}-010^{\circ} \mathrm{W}$ \\
\hline WNA & Western North America & $30^{\circ} \mathrm{N}-60^{\circ} \mathrm{N}$ & $130^{\circ} \mathrm{W}-103^{\circ} \mathrm{W}$ \\
\hline CNA & Central North America & $30^{\circ} \mathrm{N}-50^{\circ} \mathrm{N}$ & $103^{\circ} \mathrm{W}-085^{\circ} \mathrm{W}$ \\
\hline ENA & Eastern North America & $25^{\circ} \mathrm{N}-50^{\circ} \mathrm{N}$ & $085^{\circ} \mathrm{W}-050^{\circ} \mathrm{W}$ \\
\hline CAM & Central America & $10^{\circ} \mathrm{N}-30^{\circ} \mathrm{N}$ & $116^{\circ} \mathrm{W}-083^{\circ} \mathrm{W}$ \\
\hline AMZ & Amazonia & $20^{\circ} \mathrm{S}-12^{\circ} \mathrm{N}$ & $082^{\circ} \mathrm{W}-034^{\circ} \mathrm{W}$ \\
\hline SSA & Southern South America & $56^{\circ} \mathrm{S}-20^{\circ} \mathrm{S}$ & $076^{\circ} \mathrm{W}-040^{\circ} \mathrm{W}$ \\
\hline \multicolumn{4}{|c|}{ Europe-Africa } \\
\hline NEU & Northern Europe & $48^{\circ} \mathrm{N}-75^{\circ} \mathrm{N}$ & $010^{\circ} \mathrm{W}-040^{\circ} \mathrm{E}$ \\
\hline SEM & Southern Europe Mediterranean & $30^{\circ} \mathrm{N}-48^{\circ} \mathrm{N}$ & $010^{\circ} \mathrm{W}-040^{\circ} \mathrm{E}$ \\
\hline SAH & Sahara & $18^{\circ} \mathrm{N}-30^{\circ} \mathrm{N}$ & $020^{\circ} \mathrm{W}-065^{\circ} \mathrm{E}$ \\
\hline WAF & Western Africa & $12^{\circ} \mathrm{S}-18^{\circ} \mathrm{N}$ & $020^{\circ} \mathrm{W}-022^{\circ} \mathrm{E}$ \\
\hline EAF & Eastern Africa & $12^{\circ} \mathrm{S}-18^{\circ} \mathrm{N}$ & $022^{\circ} \mathrm{E}-052^{\circ} \mathrm{E}$ \\
\hline SAF & Southern Africa & $35^{\circ} \mathrm{S}-12^{\circ} \mathrm{S}$ & $010^{\circ} \mathrm{E}-052^{\circ} \mathrm{E}$ \\
\hline \multicolumn{4}{|c|}{ Asia-Australia } \\
\hline NAS & Northern Asia & $50^{\circ} \mathrm{N}-70^{\circ} \mathrm{N}$ & $040^{\circ} \mathrm{E}-180^{\circ} \mathrm{E}$ \\
\hline CAS & Central Asia & $30^{\circ} \mathrm{N}-50^{\circ} \mathrm{N}$ & $040^{\circ} \mathrm{E}-075^{\circ} \mathrm{E}$ \\
\hline TIB & Tibetan Plateau & $30^{\circ} \mathrm{N}-50^{\circ} \mathrm{N}$ & $075^{\circ} \mathrm{E}-100^{\circ} \mathrm{E}$ \\
\hline EAS & Eastern Asia & $20^{\circ} \mathrm{N}-50^{\circ} \mathrm{N}$ & $100^{\circ} \mathrm{E}-145^{\circ} \mathrm{E}$ \\
\hline SAS & Southern Asia & $05^{\circ} \mathrm{N}-30^{\circ} \mathrm{N}$ & $065^{\circ} \mathrm{E}-100^{\circ} \mathrm{E}$ \\
\hline SEA & Southeast Asia & $11^{\circ} \mathrm{S}-20^{\circ} \mathrm{N}$ & $095^{\circ} \mathrm{E}-155^{\circ} \mathrm{E}$ \\
\hline NAU & Northern Australia & $30^{\circ} \mathrm{S}-11^{\circ} \mathrm{S}$ & $110^{\circ} \mathrm{E}-155^{\circ} \mathrm{E}$ \\
\hline SAU & Southern Australia & $45^{\circ} \mathrm{S}-30^{\circ} \mathrm{S}$ & $110^{\circ} \mathrm{E}-155^{\circ} \mathrm{E}$ \\
\hline \multicolumn{4}{|c|}{ Oceans-Seas } \\
\hline NPA & Northern Pacific & $00^{\circ} \mathrm{N}-40^{\circ} \mathrm{N}$ & $150^{\circ} \mathrm{E}-120^{\circ} \mathrm{W}$ \\
\hline SPA & Southern Pacific & $55^{\circ} \mathrm{S}-00^{\circ} \mathrm{S}$ & $150^{\circ} \mathrm{E}-080^{\circ} \mathrm{W}$ \\
\hline CAR & Caribbean & $10^{\circ} \mathrm{N}-25^{\circ} \mathrm{N}$ & $085^{\circ} \mathrm{W}-060^{\circ} \mathrm{W}$ \\
\hline TNE & Tropical Northeast Atlantic & $00^{\circ} \mathrm{N}-40^{\circ} \mathrm{N}$ & $030^{\circ} \mathrm{W}-010^{\circ} \mathrm{W}$ \\
\hline MED & Mediterranean Basin & $30^{\circ} \mathrm{N}-45^{\circ} \mathrm{N}$ & $005^{\circ} \mathrm{W}-035^{\circ} \mathrm{E}$ \\
\hline IND & Indean Ocean & $35^{\circ} \mathrm{S}-17.5^{\circ} \mathrm{N}$ & $050^{\circ} \mathrm{E}-100^{\circ} \mathrm{E}$ \\
\hline
\end{tabular}

For each chosen RO variable (Sect. 2.1) we computed seasonal (DJF, MAM, JJA, SON) and annual (ANN) means from the monthly-mean data. Even though single-satellite RO measurements allow the compilation of zonal mean monthly mean climatologies, seasonal climatologies are as well commonly used (e.g. Foelsche et al., 2008a), because the sampling errors are smaller due to three times as many occultation events. The seasonal trend assessment results are then roughly representative for the individual months belonging to each season.

Regarding time periods for the trend analysis we consider three periods, which are on the one hand based on the availability of data and on the other hand on requirements for the trend analysis (roughly linear behavior of data). For ERA-40 we use the satellite era from 1980 to 2001 (restricted by the data availability until 2001), for ERA-INT the period 1989 
to 2005 as mentioned above. The GCMs are analysed for the same period as ERA-40 and in addition for the first half of the 21 st century (2001 to 2050), when the climate change signal is expected to emerge clearly from natural variability while trends are estimated to behave still approximately linearly.

\subsection{Method}

To identify geographical regions and height domains where a climate change signal emerges clearly from internal noise ("indicator region"), we perform a classical trend analysis following Wilks (2006) and Santer et al. (2000). For each data record, variable, region, height level, layer, and season, we calculate a linear trend $b$ for the respective data period of $n$ seasons or years using simple linear regression. The significance of the trends is determined via a Students $t$-test. The test value $t_{\mathrm{b}}$ is given by the ratio of the trend $b$ itself and the standard error of the trend $s_{\mathrm{b}}$,

$t_{\mathrm{b}}=\frac{b}{s_{\mathrm{b}}}=b\left((n-2)^{-1} \sum_{i=1}^{n} e_{i}^{2}\right)^{-1 / 2}\left(\sum_{i=1}^{n}\left(t_{i}-\bar{t}\right)^{2}\right)^{1 / 2}$,

where $t_{i}$ and $\bar{t}$ denote time (instantaneous time samples) and mean time (of the time samples). The standard error of the trend can be written as

$s_{\mathrm{b}}=s_{\mathrm{e}} \cdot\left(\sum_{i=1}^{n}\left(t_{i}-\bar{t}\right)^{2}\right)^{-1 / 2}$,

with the variance of the regression residuals $s_{\mathrm{e}}^{2}=\sum_{i} e_{i}^{2} /(n-$ 2).

We do not include lag-1 autocorrelation to reduce the sample size when determining the critical Students $t$-value, since it is negligible when using sliced (i.e. seasonal or annual mean) data (correlograms confirmed that autocorrelation coefficients fluctuate independently from the lag mainly between \pm 0.25 ). Beside the trends and their significances we investigate the regression's goodness of fit by means of the coefficient of determination, $R^{2}$, which can be considered as a value characterizing the signal-to-noise ratio (SNR) (Lackner et al., 2009).

The seasons influenced by the volcanic eruptions of El Chichón in 1982 and Pinatubo in 1991 were removed (also from the GCMs, as CCSM3 includes volcanic forcing in the 20 th century run). Following Santer et al. (2000), we excluded the transient volcanic signal by ignoring data from MAM 1982 to JJA 1983 and JJA 1991 to SON 1992 (1982, 1983, 1991, 1992 for annual means). Based on the results of the trend analysis, we identify our "trend indicators" as regions and height domains with significant trends at least at a $95 \%$ confidence level (we test at two levels: $95 \%$ and $99 \%$ ).

For the longer period 2001 to 2050, analysed with multiple GCM simulations, the agreement of trends from different models and simulations is an additional prerequisite to qualify as indicator region (all but one trends in A2 and
B1 simulations must have the same sign). In order to avoid highly unequal weighting of the three models, for each scenario a maximum of two simulations per model was used to determine the indicator regions. Tests showed that the indicators are essentially insensitive to the exact way the simulations are used, e.g. differences between indicators using all 20 simulations or only 10 randomly selected simulations (2 ECHAM5, 2 CCSM3, and 1 HadCM3 for each scenario) were found negligible.

\section{Results of trend analysis}

In this section, we address the question whether reanalyses and GCMs are suitable proxies for RO observations. A suitable proxy should at least succeed in reproducing the mean state of the atmosphere and in providing a realistic representation of atmospheric variability. This being satisfactory we can then proceed to the trend results themselves.

\subsection{Internal variability in RO data, reanalyses, and GCMs}

To determine the significance of trends, not only the trend magnitude but also the data variability plays an essential role. Figure 4 shows the temperature variability (calculated as the standard deviation of centered seasonal time series from which the linear trend was removed) for all seasons and the annual mean of the CHAMP RO record, the reanalyses, and the GCMs. Pressure and refractivity (not shown) exhibit variability patterns which are consistent with these temperature results.

All data sets reflect the seasonal cycle with higher variability at mid to high latitudes of the winter hemisphere. For the observational data sets (RO and reanalyses) very good agreement is given. ERA-40 and ERA-INT show very similar variability patterns. The GCM simulations exhibit generally less variability than the observations. We note that the pattern does not depend on the period or simulation considered and that long time series of pre-industrial control experiments show similar variability results. Largest discrepancies occur in the LS at low and mid-latitudes, probably as a consequence of the lack of the quasi-biennial oscillation (QBO) in GCMs. A roughly realistic tropical and subtropical LS variability is only present in CCSM3, even though the variability maximum is about $5 \mathrm{~km}$ lower than in the observations. In the tropical UT around $12 \mathrm{~km}$, enhanced observed variability is only present in DJF and partly in MAM, while ECHAM5 and HadCM3 show an increased pattern throughout all seasons.

In summary, reanalyses and GCMs reproduce the annual course of variability quite well. The seasonal patterns of spatial variations are very well presented in both reanalyses. GCMs underestimate LS variability, particularly in the tropics and subtropics. The latter has to be kept in mind for the 

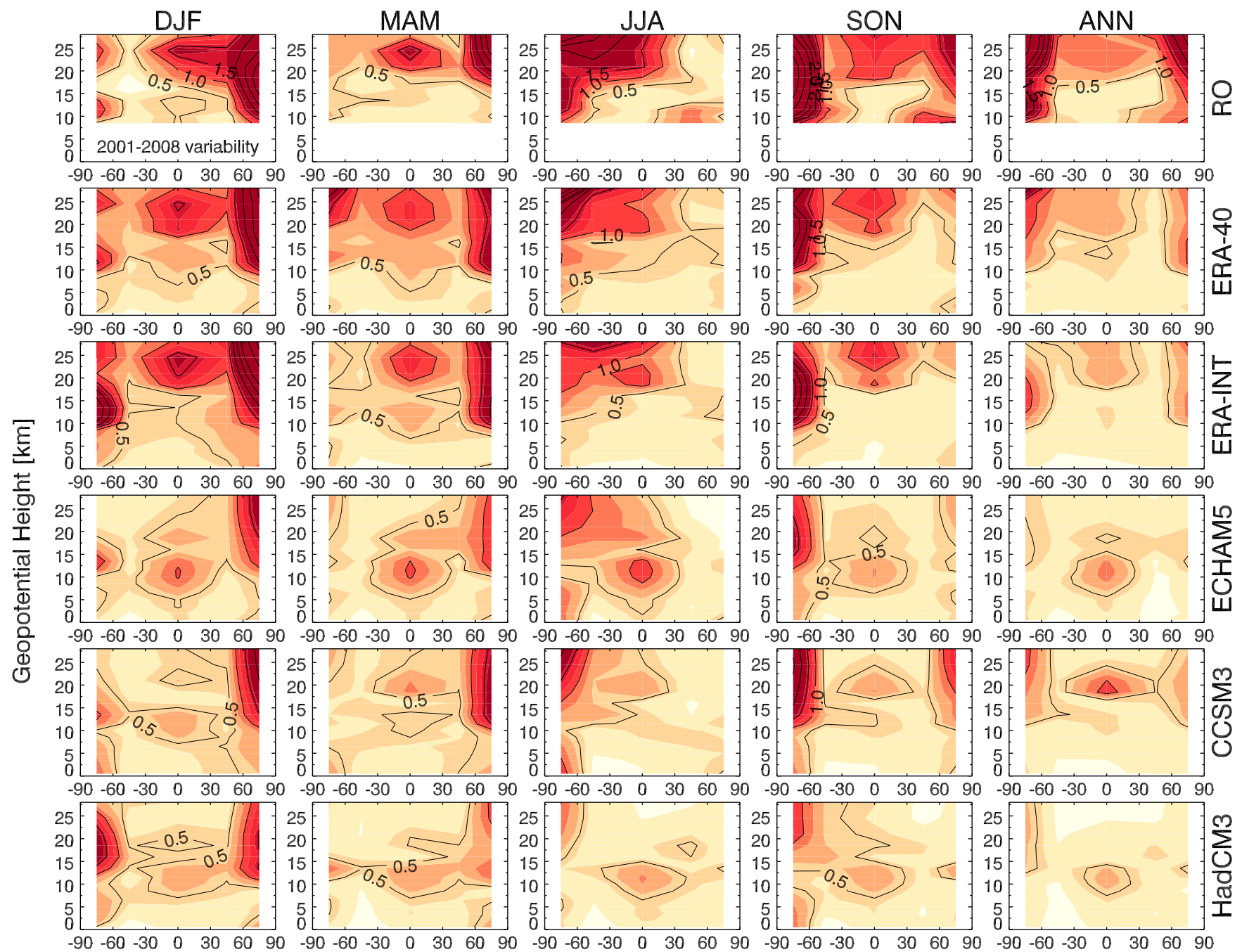

Latitude [deg]

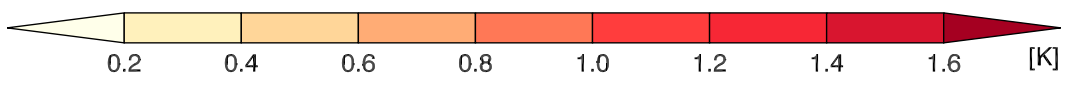

Fig. 4. Seasonal (columns DJF, MAM, JJA, SON) and annual (ANN) temperature variability (standard deviation of centered time series from which the linear trend was removed) for, from top row to bottom row, RO data (CHAMP record: September 2001 to September 2008), ERA-40 (1980 to 2001), ERA-INT (1989 to 2005), and one representative run of each of the three GCMs, ECHAM5, CCSM3, HadCM3 (1980 to 2001).

discussion of trend significances, because a small data variance and thus a smaller variance of the regression residuals will lead to higher significances than expected in real data. Overall the data are found satisfactory for the purpose of substitution of RO data here.

\subsection{Trends}

Several questions arise when analysing trends from different data sets: How well do our data sets agree with respect to global and regional trends? How large are the differences between the two reanalyses, between the GCM simulations, and between reanalyses and GCMs? Do the low model tops of GCMs have an influence on LS trends? To answer these questions we compare characteristics of GCM and ERA-40 trends from the period 1980 to 2001 . In addition, we show and discuss ERA-INT trends for 1989 to 2005 and compare ERA-40 and ERA-INT trends for 1989 to 2001. This step of the analysis provides us with the understanding of the trend data that we need to properly discuss the results with respect to the RO data.

The low top levels $(\approx 10 \mathrm{hPa})$ of the IPCC AR4 GCMs rise concern that the LS is not reliably represented in those models. This assumed deficiency may also influence the 


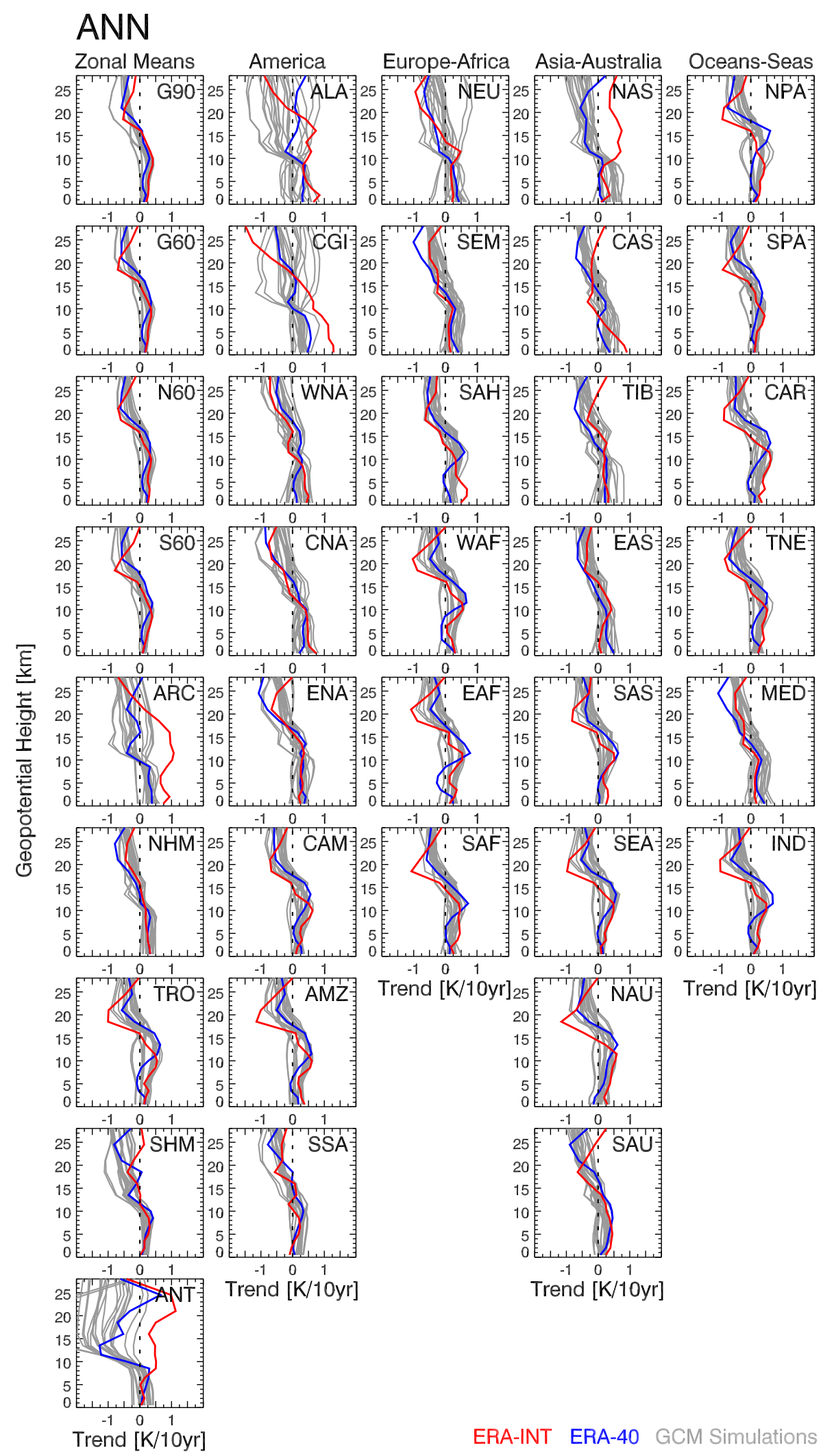

Fig. 5. 10-year temperature trends of annual means for all 37 regions of Fig. 3. ERA-INT trends (1989 to 2005) are shown in red, ERA-40 trends (1980 to 2001) in blue, and GCM trends (1980 to 2001) in grey. Trends for the large-scale zonal mean bands, as commonly provided by single-satellite RO measurements, are depicted in the leftmost column, the other columns show the results for the regions accounting to three continental sections (middle columns) and for oceans and seas (rightmost column). 

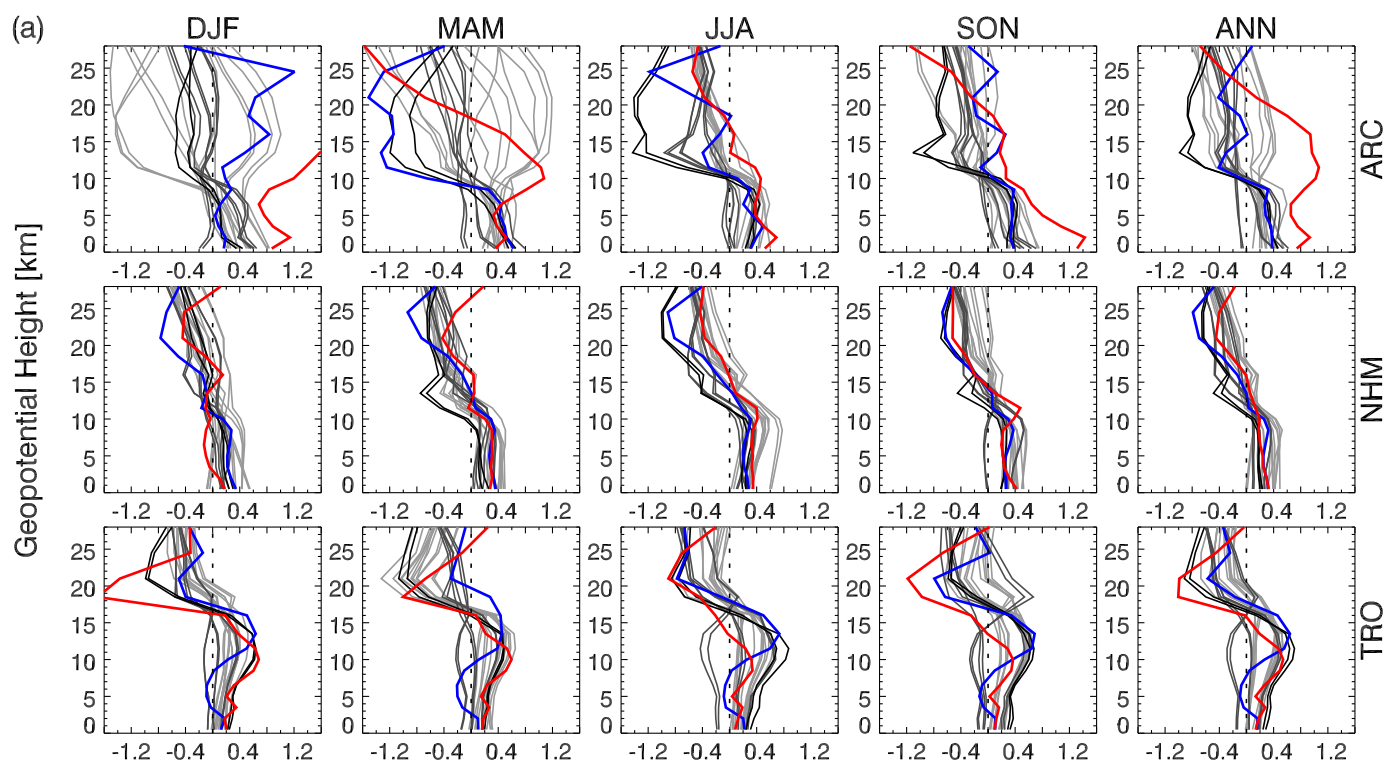

ERA-INT (1989-2005) ERA-40 (1980-2001) CCSM3

ECHAM5 HadCM3 (all 1980-2001)

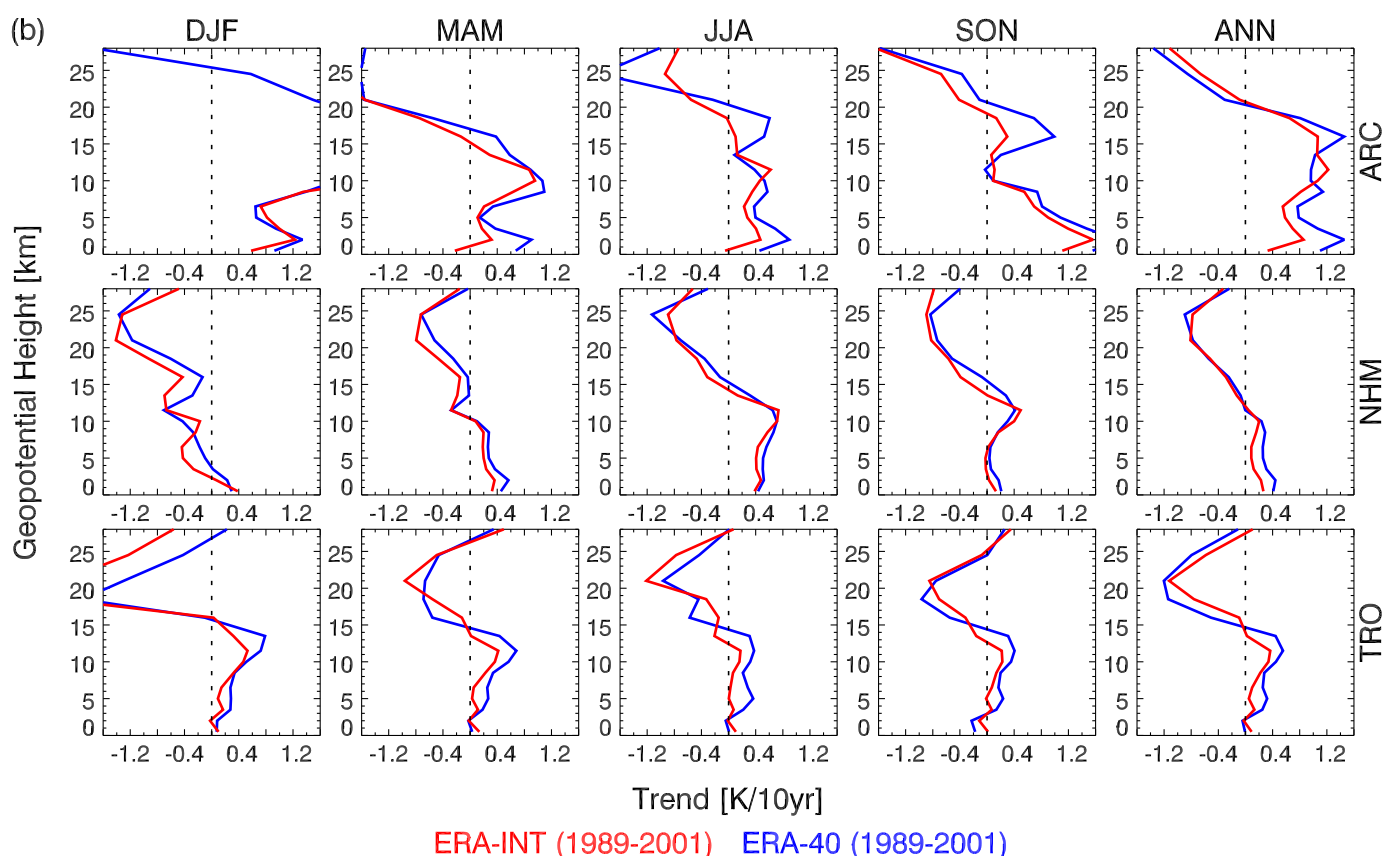

Fig. 6. 10-year temperature trends of seasonal and annual means in three selected zonal bands characterizing the high (ARC), middle (NHM) and low (TRO) latitudes. (a) ERA-INT trends in red (1989 to 2005), ERA-40 trends in blue (1980 to 2001), and GCM trends (1980 to 2001). The runs of the three models are marked in a different grey shade. (b) ERA-INT and ERA-40 trends for the period 1989 to 2001 for direct comparison of the reanalyses.

reliability of LS trend estimates. To address this we investigated first the GCM performance for LS trends by means of the Middle Atmosphere ECHAM5 Model (MAECHAM) of the Max-Planck-Institute for Meteorology, Hamburg. The MAECHAM model (Roeckner et al., 2003; Manzini et al., 2006b,a) is based on ECHAM5 but resolves the atmosphere up to $0.01 \mathrm{hPa}(\approx 80 \mathrm{~km})$ and thus can reproduce the strato- sphere as a whole. We investigated trends for the 2001 to 2025 period, based on data availability (for data set details see Foelsche et al., 2008b). Comparisons showed that the trend differences between MAECHAM and the GCM simulations are small over large-scale regions. In smaller regions and at higher latitudes the deviations are stronger and not restricted to the LS. Due to our indicator criteria (agreement of 
trends from different models and simulations), these regions will not qualify as indicator regions anyway.

Regarding trend differences, Fig. 5 shows global and regional temperature trends of annual means from ERA-INT, ERA-40, and the GCM simulations. The GCM trends are shown for the ERA-40 period. They would exhibit similar trends for the ERA-INT period 1989 to 2005. Even though single GCM runs can show varying trends in different periods, the ensemble mean trend behavior of the GCM simulations stays almost the same (i.e. in line with expectations; trends e.g. for 2000 to 2021, exhibit somewhat stronger magnitude than for 1980 to 2001 and differ in most regions less within the ensemble).

For large-scale zonal means in general, but also for several smaller-scale regional means, ERA-40, ERA-INT, and GCM trends consistently show a tropospheric warming and stratospheric cooling of around the same magnitude. Above approximately $20 \mathrm{~km}$ and throughout all seasons, ERA-INT trends are in global, hemispheric, and mid-latitudinal zonal mean regions smaller than ERA-40 and GCM trends, which show a stronger stratospheric cooling. This stratospheric ERA-INT behavior is also found in several smaller-scale regions of the extra-tropics and mid-latitudes. In the tropical and sub-tropical troposphere of zonal mean and small-scale regions, ERA-40 (and most GCM simulations) exhibits a pronounced trend maximum (approx. $0.5 \mathrm{~K} /$ decade) around $13 \mathrm{~km}$ altitude. This tropospheric trend maximum is less pronounced in ERA-INT. At higher latitudes, the deviations between the two reanalyses and between the several GCM simulations are largest, particularly in the northern winter hemisphere. There, reanalyses and GCM trends sometimes even do not agree in the sign of the trends.

This latitude dependent characteristic of trends is shown more clearly in Fig. 6, which depicts temperature trends in three selected zonal mean bands (one at high latitudes, one at mid-latitudes, and a tropical one) for all seasons and annual means. The various simulations of the three GCMs generally show similar vertical characteristics (e.g. in the midlatitudes, CCSM3 has a tendency towards more pronounced tropospheric trends than ECHAM5). Regions of smaller dimensions and higher variability, such as those at high latitudes in the winter hemisphere, generally show a stronger internal variability. GCMs evidently have problems to get reasonable trends in these regions, which is reflected by larger variation within the simulations.

ERA-40, with known deficiencies at high latitudes as shown by Santer et al. (2004) and visualized by Kehrer et al. (2008), and ERA-INT trends differ considerably in the ARC in Fig. 6a, where the ERA-INT period is about 10 years more recent than the ERA-40 period. The differences of the two reanalyses strongly decrease when the trends are based on the same time period, as shown in Fig. 6b. For these shorter trends, larger deviations between ERA-40 and ERA-INT in the ARC only remain below around $5 \mathrm{~km}$ and between $15 \mathrm{~km}$ and $20 \mathrm{~km}$ (in DJF up to $30 \mathrm{~km}$ ).
Averaging over large areas decreases the variability in general and within the GCM simulations, which is visible in the zonal means of the mid-latitudes (NHM) and tropics (TRO). ERA-40 and ERA-INT show almost consistent temperature trends if based on the same period. This indicates that in large-scale regions of low and mid-latitudes, differences between temperature trends of the two reanalyses trends are rather due to the assessed period than to native differences, particularly when annual means are considered. Good agreement of trends of individual GCM simulations in their sign is important for a reasonable definition of GCM-based RO trend indicators, because only regions with essentially all individual trends of the same sign should qualify as indicator regions (see Sect. 2.4). Thus, regions where the trends of the individual model simulations differ strongly and do not agree in the sign, such as polar caps, drop out as indicator regions when GCMs are considered.

In the tropics and the mid-latitudes, seasonal differences are small compared to regions at high latitudes. The GCMs show almost no tropical tropospheric trend seasonality, LS trends are rather small in SON compared to the other seasons. While reanalyses and the GCM ensemble mean trend agree quite well throughout all seasons in the northern midlatitudes, this is not the case if smaller-scale regions, such as Southern Europe-Mediterranean (SEM), are considered (coanalysed but not shown). There, ANN, summer, and fall seasons still show consistent trends, but DJF and MAM trends show more spread of the GCM simulations and stronger differences between the two reanalyses. ERA-INT trends are generally slightly smaller than ERA-40 trends and the GCM trends exhibit a weaker or shifted seasonal course of the trends and feature a high spread of the trends at high latitudes in winter hemispheres.

In summary, ERA-40, ERA-INT, and GCM ensemble mean trends are consistent as long as large-scale regions at low and mid-latitudes are considered. Therefore, while showing the results below for all zonal mean bands for full transparency and completeness, we will focus on the largescale and non-polar regions. Also we focus the discussion the the results above $8.5 \mathrm{~km}$ (due to the dry air assumption, see Sect. 2.1).

\section{Discussion with respect to $\mathrm{RO}$ indicators}

Based on the results of the trend analysis, we here understand the trend indicators as variables in regions in which the proxies for RO (GCMs and reanalyses) feature a high SNR. In doing so we implicitly assume that these data respond similar to external forcings as actual RO data would do and show comparable internal variability. As the findings of the last section showed, this assumption is acceptable if we interpret the results with due care for the uncertainties found involved. 

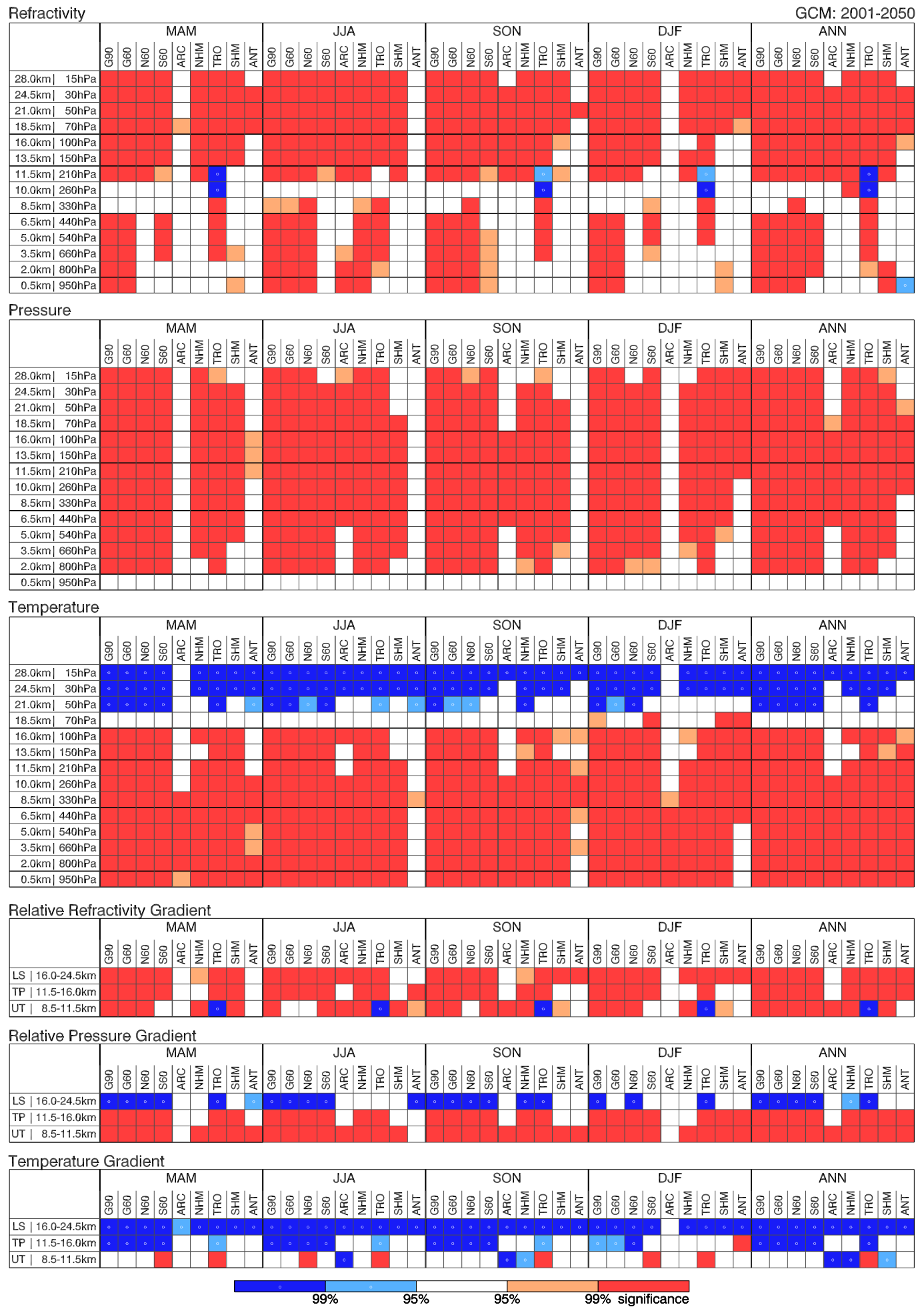

Fig. 7. Trend indicators based on 10 selected GCM simulations for the period 2001 to 2050 for the RO-accessible variables refractivity, pressure, temperature, relative refractivity gradient, relative pressure gradient, and temperature gradient (from top to bottom). Results are shown for large-scale zonal means (as defined in Fig. 3) at all investigated height levels and layers, for all seasons and for the annual mean (left to right). Positive trends are red coloured, negative trends in blue. Trend significances greater than $99 \%$ are marked by dark colours, significances greater than $95 \%$ by light colours. 

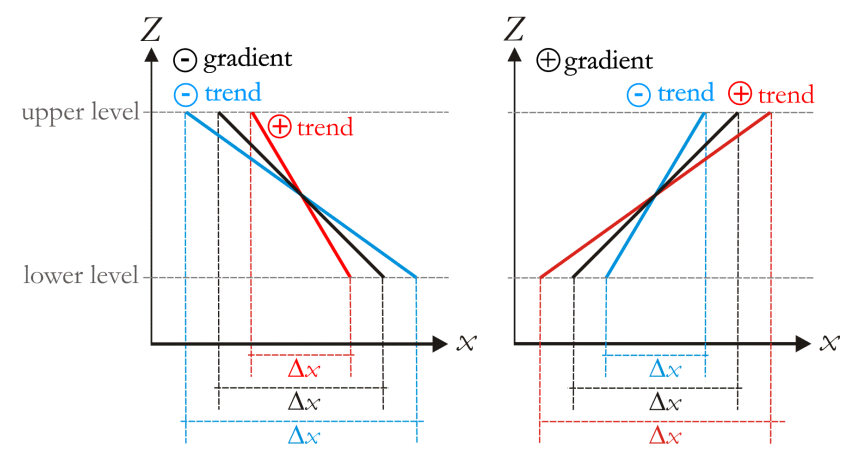

Fig. 8. Schematic illustration of negative and positive variable gradient (upper level value minus lower level value) and its trends.

\subsection{RO-accessible trend indicators based on GCM sim- ulations 2001 to 2050}

The GCM-based indicator regions for the trends of the first part of the 21st century are illustrated for all variables in Fig. 7 (the colour shade indicates trend significances of $95 \%$ and $99 \%)$. For the level-based analysis, the results of all zonal mean regions, except the polar caps, generally coincide very well throughout seasons at single height levels. For the layer trends, the tropics and mid-latitudes, depending on the season, stand out as indicator regions in addition.

Refractivity, the RO variable closest to bending angle (on the applicability of the latter for climate change detection see Ringer and Healy, 2008), turns out as suitable LS and TP indicator in all large-scale zonal regions. Only in DJF, the midlatitudes do not qualify as TP indicator regions. An interesting feature emerges for the tropical UT around $10 \mathrm{~km}$ altitude, an indicator region based on negative refractivity trends in all seasons but JJA. This feature will recur in the reanalyses. Pressure emerges as RO indicator for the whole UTLS. Significant trends extend down to near surface for global and hemispheric means. The temperature indicators reflect the variation in height of the simulations' crossing points from tropospheric warming to stratospheric cooling near around $18 \mathrm{~km}$. Global and hemispheric means qualify consistently in all time domains as indicator regions above $21 \mathrm{~km}$ and below $16 \mathrm{~km}$. Concerning the zonal bands, best results are gained for the tropics. The mid- and high-latitudinal bands reflect the higher variability of the respective winter season so that tropospheric indicators are constrained to the top levels and to below around $10 \mathrm{~km}$.

The layer gradients of refractivity and pressure, as well as of UT and TP temperature, have negative values. A negative gradient implies that the variable values decrease with increasing height. Only LS temperature features positive gradients. Thus, a positive gradient trend results from an increase of positive gradients or from a decrease of negative gradients (see Fig. 8). Vice versa, negative gradient trends imply a growth of negative gradients and a decline of positive gradients.
All LS and TP layer gradients turn out as indicators for global and hemispheric means. Refractivity gradient trends are predominantly positive. The strong LS refractivity gradient trend signal is consistent with a model study of Ringer and Healy (2008), who showed that the bending angle climate change signal in the tropical UTLS may become distinguishable from natural variability after approximately ten to sixteen years of measurements. A refractivity gradient exception is the UT tropical band with pronounced negative gradient trends throughout all seasons. This tropical pattern is reflected as positive trend in temperature gradients. The tropical band provides besides the global and hemispheric means the most promising region in all variable gradients and for all layers.

The mid-latitudes mirror seasonal variability and show promise for trend indicator regions of the respective summer seasons. LS pressure gradient trends are negative because of a gradient increase, which is due to the most pronounced pressure trend signal at around $15 \mathrm{~km}$ height (cf. Fig. 2). Temperature gradient trends are most pronounced in the LS and for global and hemispheric means in the TP. These negative gradient trends indicate a continuous enhancement of LS cooling with height. From GCM proxies, the "typical" RO variables refractivity and pressure alone are adequate indicators for the UTLS, but temperature and most notably layer gradients provide valuable additional information, mainly in the tropics.

\subsection{ERA-40 based RO-accessible trend indicators}

The results for ERA-40 indicators of the 1980 to 2001 period are presented for all variables in Fig. 9. The criterion to qualify as indicator is based on trend significance $(95 \%$ or $99 \%$ ). Compared to the 50-year GCM trend results, the ERA-40 indicators are stronger limited to certain height levels and regions and show more seasonality. Trend significances are in general lower than they are for the 50-year GCM trends, which is due to the shorter trend period and the stronger, more RO-like, internal variability (cf. Fig. 4).

The UTLS refractivity indicators, based on positive trends, are centered at $21 \mathrm{~km}$ height and best pronounced for global and hemispheric means. In the tropical and mid-latitudinal LS regions, refractivity is an acceptable indicator only in SON and ANN. For MAM and ANN, sound results are gained in the TP height region. Similar to the long-term GCM trends, but more pronounced, negative highly significant trends appear in the tropics around $11.5 \mathrm{~km}$ throughout all seasons. Besides the tropics, Antarctica provides eye-catching negative LS indicators (also for pressure fields). These indicators must be seen with reservation, however, as the quality of ERA-40 is deficient at high southern latitudes according to Santer et al. (2004) and visualized by Kehrer et al. (2008) and Ladstädter et al. (2010). The seasonal dependence of ERA-40 indicators is also reflected in pressure. Most robust results emerge in the TP region (extending into 

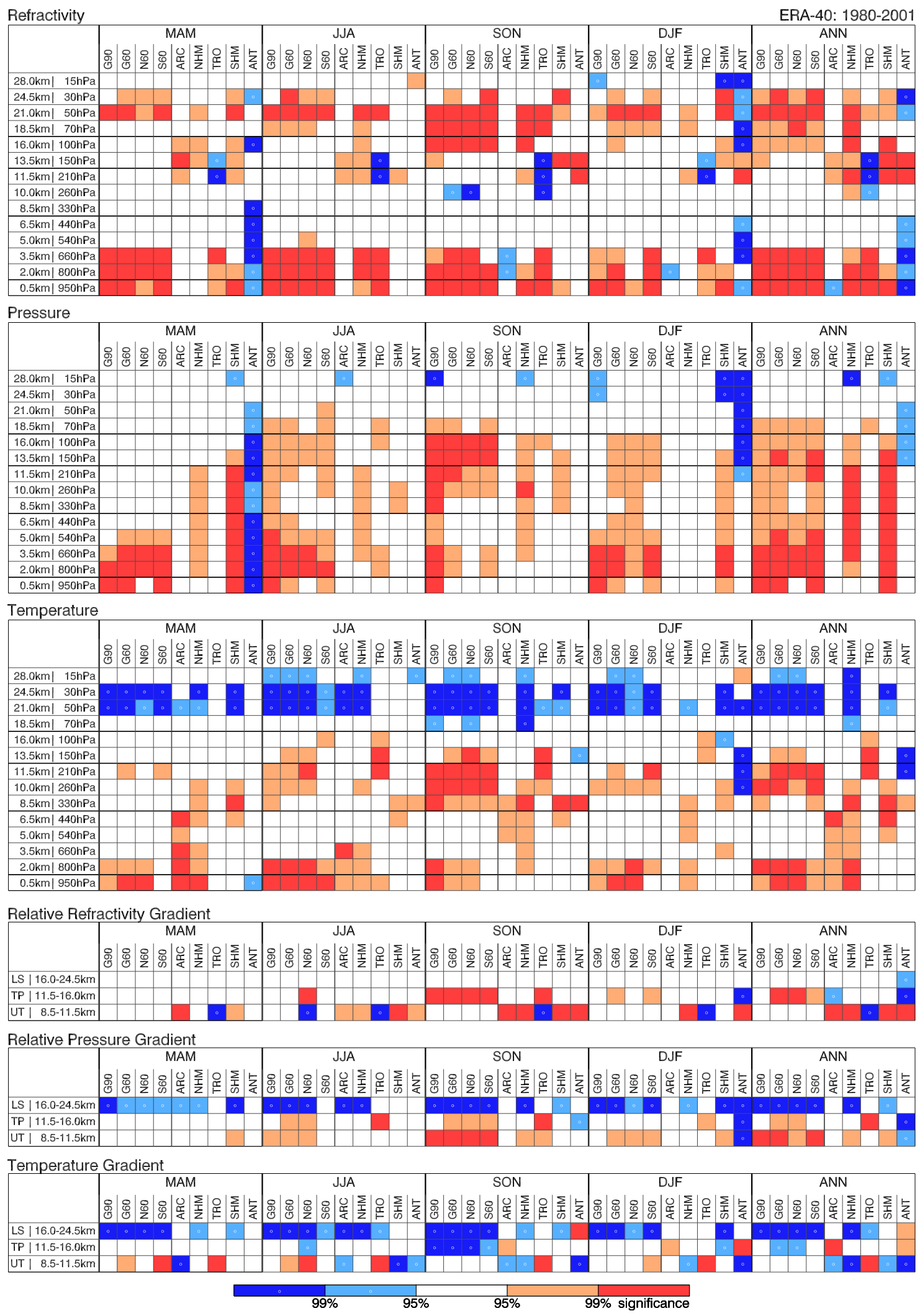

Fig. 9. Trend indicators based on ERA-40 for the period 1980 to 2001 for the RO-accessible variables refractivity, pressure, temperature, relative refractivity gradient, relative pressure gradient, and temperature gradient (from top to bottom). Same layout as Fig. 7. 
the UT) in SON and with lower significance in ANN, JJA, and DJF.

The mid-latitudes appear as indicator regions in SON and ANN for the UTLS. Tropical pressure trends show low significances in contrast to refractivity and temperature. ERA40 temperature trends are significant in the LS over all seasons. Besides the large-scale regions, the mid-latitudes exhibit highly significant trends in MAM, SON, and ANN, and in the respective summer hemisphere. In the UT, global and hemispheric mean regions prove as highly significant indicators in SON and ANN. Around $11.5 \mathrm{~km}$, analogous to refractivity, the tropics serve as indicators in all seasons but MAM.

Layer indicators for ERA-40 refractivity show a strong seasonality. The global and hemispheric mean indicators are restricted to the TP (SON, ANN). The zonal bands turn out as indicators in the UT in SON, ANN, and JJA. The most striking relative refractivity gradient indicator is based on the strong negative refractivity trends in the tropical UT in all seasons, which is consistent with the GCM results. The relative pressure gradients exhibit LS indicators for global and hemispherical means and the mid-latitudes in all seasons. The tropics show good indicator results for the TP in all seasons but MAM. For the UT only SON and ANN trends are mentionable. The temperature gradients show promising results in the LS with less significant trends in the tropics. In the TP, temperature gradient indicators are almost exclusively restricted to SON and ANN. Similar to the refractivity gradients, the UT temperature gradients are significant for zonal mean bands in general and for the tropical region in particular.

Compared to the GCMs, ERA-40 indicators show, in line with expectations from Sect. 3, stronger characteristics at certain distinct height ranges and more seasonality. Regarding geographic regions, not surprisingly the large-scale means (G90, G60, N60, S60) and the tropics, but also the mid-latitudes come out as most interesting regions, where climate change should be traced. Even though the GCMs show less seasonality in their indicators, their behavior is similar to ERA-40, with best SNR in SON, ANN, and JJA.

\subsection{ERA-INT based RO-accessible trend indicators}

The ERA-INT based trend indicators are used to cross-check the robustness of ERA-40 trends in time, as the ERA-INT trend period is shifted by around 10 years compared to the ERA-40 period. The ERA-INT trend indictors are shown in Fig. 10. An overall comparison with ERA-40 indicators (Fig. 9) shows that ERA-INT indicators are even stronger confined to certain regions and seasons, which is also partly due to the shorter ERA-INT period used for the trend calculation. The Arctic drops out as indicator region in ERAINT, which indicates that the newer reanalysis has overcome shortcomings of ERA-40 at high southern latitudes.

LS and TP refractivity indicators are best pronounced between $13.5 \mathrm{~km}$ and $21 \mathrm{~km}$ in global and hemispheric means in
SON and ANN. Besides these large-scale means, the Arctic comes out as LS, TP, and partly UT indicator region in ANN, $\mathrm{SON}$, and JJA. Around $8.5 \mathrm{~km}$, significant negative trends emerge in large-scale regions in ANN and in the tropics in all seasons but SON. Compared to ERA-40, the indicator height is shifted about $1 \mathrm{~km}$ to $2 \mathrm{~km}$ downwards (cf. to the UT tropical trends in Fig. 6). Pressure indicators are mainly limited to the UT and TP in SON and ANN. The Arctic exhibits again eye-catching positive trends in ANN and SON over the entire UT, TP, and most of the LS region. ERA-INT LS temperature indicators emerge around $21 \mathrm{~km}$ in large-scale means in all seasons but JJA. In the UT, again SON and ANN show the best indicator results in global and hemispheric means and in the tropics.

ERA-INT develops layer gradient indicators mainly for global and hemispheric means and the tropics. The midlatitudes show only significant trends in hemispheric summer seasons. The refractivity gradient indicators are primarily limited to the LS and TP in SON and ANN. Pressure gradients are very similar to ERA-40 and well defined in LS and UT in ANN, MAM, and SON. Temperature gradient indicators are in contrast to ERA-40 restricted to the TP in ANN, JJA, and SON in hemispheric and large-scale means and partly the tropics.

ERA-INT trends exhibit in the analysed regions generally less significance than ERA-40 trends do. In addition, those regions with highly significant trends are much more tied to the seasons SON and ANN. Consistent with GCMs and ERA-40, global and hemispheric means, the tropics, and summer hemispherical mid-latitudes are promising candidates to robustly track climate change by RO. The sensitivity of the variables at different height ranges and in different seasons confirms the potential of the RO data record for climate monitoring.

\section{Summary and conclusions}

RO-accessible variables were systematically explored regarding their long-term climate trend monitoring utility in different seasons, regions, and height ranges, based on proxy data to fill in for the still short RO record. These data comprised climate simulations of three representative IPCC AR4 models (ECHAM5, CCSM3, HadCM3, investigated for 2001 to 2050), the ERA-40 (1980 to 2001), and the ERAINT (1989 to 2005) reanalysis. The adequacy of these proxies for the RO record was demonstrated by means of comparative variability and trend investigations. The latter included an analysis of GCM's LS trends compared to those of the middle atmosphere version of the ECHAM5 model, MAECHAM. We found that the LS trend performance of models with the uppermost level at $10 \mathrm{hPa}$ shows no striking differences to middle atmosphere model trends (top level at $0.01 \mathrm{hPa}$ ) in large-scale regions, supporting that we could use the GCM data as proxies for RO also in the LS. For the 

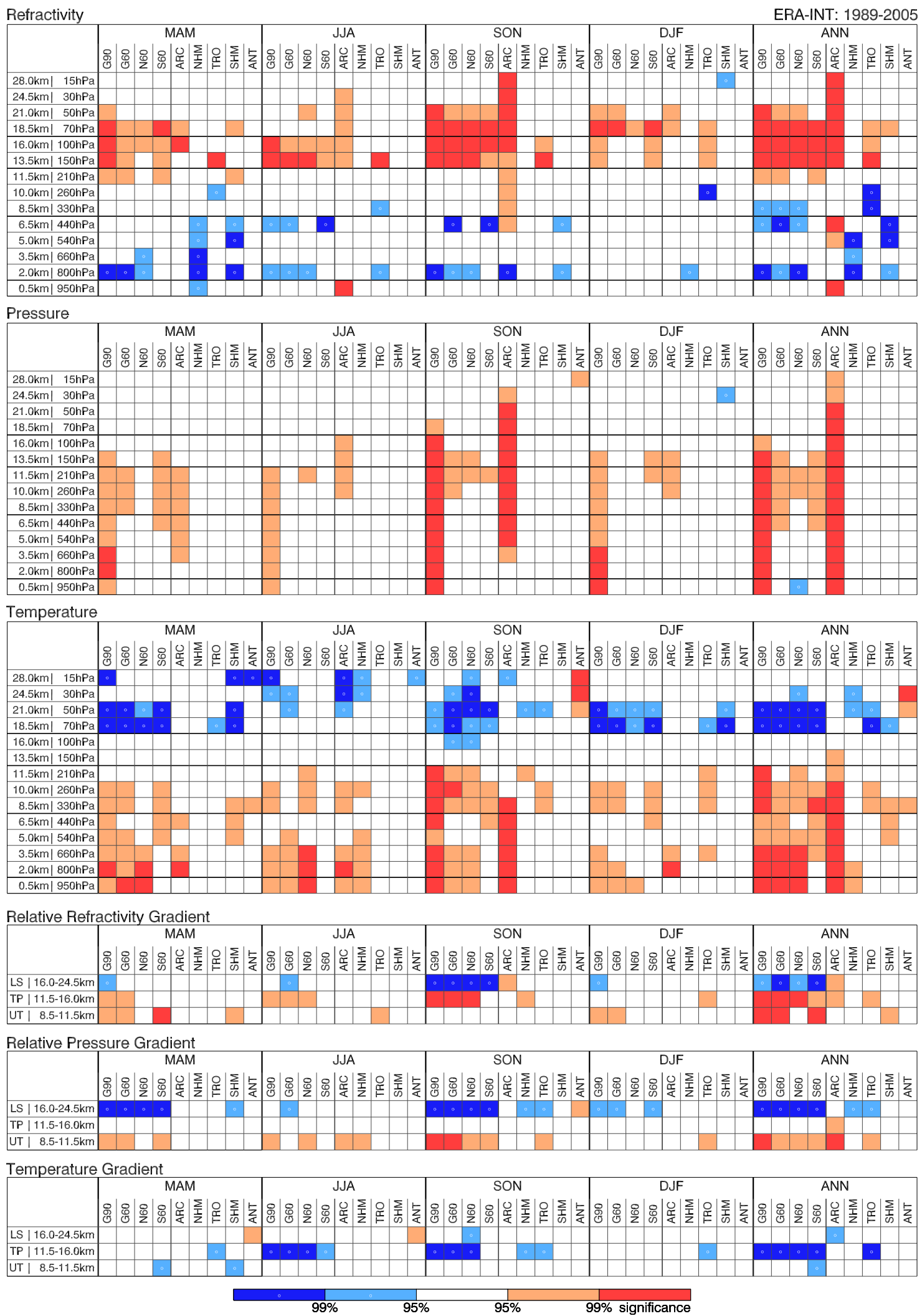

Fig. 10. Trend indicators based on ERA-INT for the period 1989 to 2005 for the RO-accessible variables refractivity, pressure, temperature, relative refractivity gradient, relative pressure gradient, and temperature gradient (from top to bottom). Same layout as Fig. 7. 
trend analysis we concentrated on large-scale zonal means of the RO variables refractivity, pressure, and temperature in terms of single level trends and layer gradient trends. Indicators were defined as regions with high SNR of trends over variability, determined by trend significance and - for GCMs - by the agreement of the single simulations in their trend sign.

The GCMs showed for the years 2001 to 2050 a strong climate change signal in most height domains. Model-based zonal mean trends are significant in all seasons. The shorter period of analysed ERA-40 trends, 1980 to 2001, draws a more narrowed picture of regions with high SNR. Single zonal bands, especially the tropical region and mid-latitudes, turn out as good indicator regions for several variables and height domains. Compared to the GCMs, ERA-40 indicator regions are not equally distributed throughout all seasons. SON, ANN, and JJA exhibit best indicator results for the UTLS, which supports the added value of seasonal monitoring of climate change by RO. Nevertheless, GCM and ERA-40 results are generally consistent in regard of indicators. ERA-INT trend significance is even more confined to certain regions, height domains, and seasons than ERA40 trends. SON and ANN arise as most promising seasons, global and hemispheric means and the tropics as most suitable regions for tracking climate change.

In terms of variables and height levels, refractivity turned out as good indicator around $18 \mathrm{~km}$ height, pressure follows on lower levels around $13 \mathrm{~km}$, and temperature even lower around $9 \mathrm{~km}$ height. The latter also emerges as LS indicator around $21 \mathrm{~km}$. Besides the level-based considerations, layer gradients support the applicability of RO data for climate monitoring and show promising results. When the boundary height levels of the layers used to calculate gradients are properly chosen, the layer gradients appear more sensitive to climate change in wider regions than single level data do, providing additional information. In this respect, improved results will be gained from real RO data (provided some more years of measurements are available), which feature a much better vertical resolution than GCMs or reanalyses could provide.

Overall, the set of the analysed RO-accessible variables qualifies for climate monitoring in the whole UTLS, since the variability of the variables differs with height. For the UTLS, the RO focus region, refractivity and pressure and the respective layer gradients alone are adequate trend indicators. Temperature can be used as additional indicator, which facilitates as commonly used variable the interpretation of results. The analysis of the ERA-40 trends and the more recent ERA-INT trends support not only the investigation of annual means, but also the use of the season SON for early climate signal detections. Besides global and hemispheric means, the tropical region and partly the mid-latitudes turned out as favoured regions for climate trend studies. By end 2011, a continuous monthly mean RO record of 10 years, and - including the GPS/Met data - an intermitted record of 15 years will be available for climate studies in the discussed domains allowing a more detailed look into vertical characteristics of climate change over at least a decade.

Acknowledgements. We acknowledge the modeling groups, the Program for Climate Model Diagnosis and Intercomparison (PCMDI) and the WCRP's Working Group on Coupled Modelling (WGCM) for their roles in making available the WCRP CMIP3 multi-model dataset. Support of this dataset is provided by the Office of Science, US Department of Energy. ECMWF (Reading, UK) ERA-40 and ERA-Interim data used in this study have been obtained from the ECMWF data server. The authors acknowledge UCAR (Boulder, CO) for CHAMP, Formosat-3/COSMIC, and GRACE RO excess phase and orbit data. B. Scherllin-Pirscher, J. Fritzer, and U. Foelsche (Wegener Center) are thanked for their efforts in RO processing development and climatology preparations, RO processing development was mainly funded by ESA/ESTEC Noordwijk and FFG/ALR Austria. This work was funded by the Austrian Science Fund (FWF) Projects INDICATE P18733-N10 and TRENDEVAL P21642-N21.

Topical Editor P. Drobinski thanks K. Hocke and another anonymous referee for their help in evaluating this paper.

\section{References}

Andrews, D. G., Holton, J. R., and Leovy, C. B.: Middle Atmosphere Dynamics, Academic Press, Orlando, San Diego, New York, Austin, Boston, London, Sydney, Tokyo, Toronto, 1987.

Anthes, R. A.: Exploring Earth's atmosphere with radio occultation: contributions to weather, climate and space weather, Atmos. Meas. Tech., 4, 1077-1103, doi:10.5194/amt-4-1077-2011, 2011.

Anthes, R. A., Ector, D., Hunt, D. C., Kuo, Y.-H., Rocken, C., Schreiner, W. S., Sokolovskiy, S. V., Syndergaard, S., Wee, T.K., Zeng, Z., Bernhardt, P. A., Dymond, K. F., Chen, Y., Liu, H., Manning, K., Randel, W. J., Trenberth, K. E., Cucurull, L., Healy, S. B., Ho, S.-P., McCormick, C., Meehan, T. K., Thompson, D. C., and Yen, N. L.: The COSMIC/FORMOSAT3 mission: early results, B. Am. Meteorol. Soc., 89, 313-333, doi:10.1175/BAMS-89-3-313, 2008.

Beyerle, G., Schmidt, T., Michalak, G., Heise, S., Wickert, J., and Reigber, C.: GPS radio occultation with GRACE: Atmospheric profiling utilizing the zero difference technique, Geophys. Res. Lett., 32, L13806, doi:10.1029/2005GL023109, 2005.

Christensen, J. H., Hewitson, B., Busuioc, A., Chen, A., Gao, X., Held, I., Jones, R., Kolli, R. K., Kwon, W.-T., Laprise, R., Magaña Rueda, V., Mearns, L., Menéndez, C. G., Räisänen, J., Rinke, A., Sarr, A., and Whetton, P.: Regional Climate Projections, in: Climate Change 2007: The Physical Science Basis. Contribution of Working Group I to the Fourth Assessment Report of the Intergovernmental Panel on Climate Change, edited by: Solomon, S., Qin, D., Manning, M., Chen, Z., Marquis, M., Averyt, K. B., Tignor, M., and Miller, H. L., pp. 847-940, Cambridge University Press, 2007.

Collins, W. D., Bitz, C. M., Blackmon, M. L., Bonan, G. B., Bretherton, C. S., Carton, J. A., Chang, P., Doney, S. C., Hack, J. J., Henderson, T. B., Kiehl, J. T., Large, W. G., McKenna, D. S., Santer, B. D., and Smith, R. D.: The community climate 
system model version 3 (CCSM3), J. Climate, 19, 2122-2143, doi:10.1175/JCLI3761.1, 2006.

Foelsche, U., Borsche, M., Steiner, A. K., Gobiet, A., Pirscher, B., Kirchengast, G., Wickert, J., and Schmidt, T.: Observing upper troposphere-lower stratosphere climate with radio occultation data from the CHAMP satellite, Clim. Dynam., 31, 49-65, doi:10.1007/s00382-007-0337-7, 2008a.

Foelsche, U., Kirchengast, G., Steiner, A. K., Kornblueh, L., Manzini, E., and Bengtsson, L.: An observing system simulation experiment for climate monitoring with GNSS radio occultation data: Setup and test bed study, J. Geophys. Res., 113, D11108, doi:10.1029/2007JD009231, 2008b.

Foelsche, U., Pirscher, B., Borsche, M., Kirchengast, G., and Wickert, J.: Assessing the climate monitoring utility of radio occultation data: From CHAMP to FORMOSAT3/COSMIC, Terr. Atmos. Ocean. Sci., 20, 155-170, doi:10.3319/TAO.2008.01.14.01(F3C), 2009.

Foelsche, U., Scherllin-Pirscher, B., Ladstädter, F., Steiner, A. K., and Kirchengast, G.: Refractivity and temperature climate records from multiple radio occultation satellites consistent within $0.05 \%$, Atmos. Meas. Tech., 4, 2007-2018, doi:10.5194/amt-4-2007-2011, 2011.

Forster, P. M., Bodeker, G., Schofield, R., Solomon, S., and Thompson, D.: Effects of ozone cooling in the tropical lower stratosphere and upper troposphere, Geophys. Res. Lett., 34, L23813, doi:10.1029/2007GL031994, 2007.

Gordon, C., Cooper, C., Senior, C. A., Banks, H., Gregory, J. M., Johns, T. C., Mitchell, J. F. B., and Wood, R. A.: The simulation of SST, sea ice extents and ocean heat transports in a version of the Hadley Centre coupled model without flux adjustments, Clim. Dynam., 16, 147-168, doi:10.1007/s003820050010, 2000.

Hajj, G. A., Kursinski, E. R., Romans, L. J., Bertiger, W. I., and Leroy, S. S.: A technical description of atmospheric sounding by GPS occultation, J. Atmos. Sol. Terr. Phys., 64, 451-469, doi:10.1016/S1364-6826(01)00114-6, 2002.

Hajj, G. A., Ao, C. O., Iijima, B. A., Kuang, D., Kursinski, E. R., Mannucci, A. J., Meehan, T. K., Romans, L. J., de La Torre Juarez, M., and Yunck, T. P.: CHAMP and SAC$\mathrm{C}$ atmospheric occultation results and intercomparisons, J. Geophys. Res., 109, D06109, doi:10.1029/2003JD003909, 2004.

Healy, S. B. and Eyre, J. R.: Retrieving temperature, water vapour and surface pressure information from refractive-index profiles derived by radio occultation: A simulation study, Q. J. Roy. Meteorol. Soc., 126, 1661-1683, doi:10.1002/qj.49712656606, 2000.

Held, I. M. and Soden, B. J.: Robust responses of the hydrological cycle to global warming, J. Climate, 19, 5686-5699, doi:10.1175/JCLI3990.1, 2006.

Ho, S.-P., Kirchengast, G., Leroy, S., Wickert, J., Mannucci, A. J., Steiner, A., Hunt, D., Schreiner, W., Sokolovskiy, S., Ao, C., Borsche, M., von Engeln, A., Foelsche, U., Heise, S., Iijima, B., Kuo, Y.-H., Kursinski, R., Pirscher, B., Ringer, M., Rocken, C., and Schmidt, T.: Estimating the uncertainty of using GPS radio occultation data for climate monitoring: Intercomparison of CHAMP refractivity climate records from 2002 to 2006 from different data centers, J. Geophys. Res., 114, D23107, doi:10.1029/2009JD011969, 2009.

Holton, J. R.: An introduction to dynamic meteorology, vol. 88 of International geophysics series, Academic Press, Amsterdam, 4. edn., 2004.

Karl, T. R., Hassol, S. J., Miller, C. D., and Murray, W. L.: Temperature Trends in the Lower Atmosphere: Steps for Understanding and Reconciling Differences, A report by the US Climate Change Science Program and the Subcommittee on Global Change Research, Washington, D.C., 2006.

Kehrer, J., Ladstadter, F., Muigg, P., Doleisch, H., Steiner, A., and Hauser, H.: Hypothesis generation in climate research with interactive visual data exploration, IEEE T. Vis. Comput. Gr., 14, 1579-1586, doi:10.1109/TVCG.2008.139, 2008.

Kursinski, E. R. and Hajj, G. A.: A comparison of water vapor derived from GPS occultations and global weather analyses, J. Geophys. Res., 106, 1113-1138, doi:10.1029/2000JD900421, 2001.

Kursinski, E. R., Hajj, G. A., Schofield, J. T., Linfield, R. P., and Hardy, K. R.: Observing Earth's atmosphere with radio occultation measurements using the Global Positioning System, J. Geophys. Res., 102, 23429-23465, doi:10.1029/97JD01569, 1997.

Lackner, B. C.: Exploring trend indicators of climate change from radio occultation and optimal trend detection (Ph.D. thesis), Scientific Report 38-2010, Wegener Center Verlag, Graz, Austria, 2010.

Lackner, B. C., Steiner, A. K., Ladstädter, F., and Kirchengast, G.: Trend indicators of atmospheric climate change based on global climate model scenarios, in: New Horizons in Occultation Research: Studies in Atmosphere and Climate, edited by: Steiner, A. K., Pirscher, B., Foelsche, U., and Kirchengast, G., pp. 245258, Springer Berlin Heidelberg, 2009.

Lackner, B. C., Steiner, A. K., Hegerl, G. C., and Kirchengast, G.: Atmospheric climate change detection by radio occultation data using a fingerprinting method, J. Climate, 24, 5275-5291, doi:10.1175/2011JCLI3966.1, 2011.

Ladstädter, F., Steiner, A. K., Lackner, B. C., Pirscher, B., Kirchengast, G., Kehrer, J., Hauser, H., Muigg, P., and Doleisch, H.: Exploration of climate data using interactive visualization, J. Atmos. Ocean. Tech., 27, 667-679, doi:10.1175/2009JTECHA1374.1, 2010.

Leroy, S. S.: Measurement of geopotential heights by GPS radio occultation, J. Geophys. Res., 102, 6971-6986, doi:10.1029/96JD03083, 1997.

Leroy, S., Dykema, J., and Anderson, J.: Climate benchmarking using GNSS occultation, in: Atmosphere and Climate, edited by: Foelsche, U., Kirchengast, G., and Steiner, A., pp. 287-301, Springer Berlin Heidelberg, doi:10.1007/3-540-341218_24, 2006

Loiselet, M., Stricker, N., Menard, Y., and Luntama, J.-P.: Metop's GPS based Atmospheric sounder, ESA Bulletin, 102, 38-44, 2000.

Luntama, J.-P., Kirchengast, G., Borsche, M., Foelsche, U., Steiner, A., Healy, S., von Engeln, A., O'Clerigh, E., and Marquardt, C.: Prospects of the EPS GRAS mission for operational atmospheric applications, B. Am. Meteorol. Soc., 89, 1863-1875, doi:10.1175/2008BAMS2399.1, 2008.

Manzini, E., Giorgetta, M. A., Esch, M., Kornblueh, L., and Roeckner, E.: The influence of sea surface temperatures on the Northern winter stratosphere: Ensemble simulations with the MAECHAM5 model, J. Climate, 19, 3863-3881, doi:10.1175/JCLI3826.1, 2006a.

Manzini, E., Roeckner, E., Esch, M., and Bengtsson, L.: Climatology and forcing of the quasi-biennial oscillation 
in the MAECHAM5 model, J. Climate, 19, 3882-3901, doi:10.1175/JCLI3830.1, 2006b.

Nakićenović, N., Alcamo, J., Davis, G., de Vries, B., Fenhann, J., Gaffin, S., Gregory, K., Grúbler, A., Jung, T. Y., Kram, T., La Rovere, E. L., Michaelis, L., Mori, S., Morita, T., Pepper, W., Pitcher, H., Price, L., Riahi, K., Roehrl, A., Rogner, H.-H., Sankovski, A., Schlesinger, M., Shukla, P., Smith, S., Swart, R., van Rooijen, S., Victor, N., and Dadi, Z.: IPCC Special Report on Emissions Scenarios, Cambridge University Press, UK., 2000.

National Oceanic Atmospheric Administration, National Aeronautics and Space Administration, and United States Air Force: U.S. Standard Atmosphere 1976, US Government Printing Office, Washington, D.C., 1976.

Pirscher, B.: Multi-satellite climatologies of fundamental atmospheric variables from radio occultation and their validation (Ph.D. thesis), Scientific Report 33-2010, Wegener Center Verlag, Graz, Austria, 2010.

Pirscher, B., Foelsche, U., Lackner, B. C., and Kirchengast, G.: Local time influence in single-satellite radio occultation climatologies from Sun-synchronous and non-Sun-synchronous satellites, J. Geophys. Res., 112, D11119, doi:10.1029/2006JD007934, 2007.

Poli, P., Healy, S. B., and Dee, D. P.: Assimilation of global positioning system radio occultation data in the ECMWF ERAInterim reanalysis, Q. J. Roy. Meteorolog. Soc., 136, 1972-1990, doi:10.1002/qj.722, 2010.

Pope, V. D., Gallani, M. L., Rowntree, P. R., and Stratton, R. A.: The impact of new physical parametrizations in the Hadley Centre climate model: HadAM3, Clim. Dynam., 16, 123-146, doi:10.1007/s003820050009, 2000.

Randel, W. J., Shine, K. P., Austin, J., Barnett, J., Claud, C., Gillett, N. P., Keckhut, P., Langematz, U., Lin, R., Long, C., Mears, C., Miller, A., Nash, J., Seidel, D. J., Thompson, D. W. J., Wu, F., and Yoden, S.: An update of observed stratospheric temperature trends, J. Geophys. Res., 114, D02107, doi:10.1029/2008JD010421, 2009.

Reichler, T. and Kim, J.: Uncertainties in the climate mean state of global observations, reanalyses, and the GFDL climate model, J. Geophys. Res., 113, D05106, doi:10.1029/2007JD009278, 2008.

Ringer, M. A. and Healy, S. B.: Monitoring twenty-first century climate using GPS radio occultation bending angles, Geophys. Res. Lett., 35, L05708, doi:10.1029/2007GL032462, 2008.

Rocken, C., Anthes, R., Exner, M., Hunt, D., Sokolovskiy, S., Ware, R., Gorbunov, M., Schreiner, W., Feng, D., Herman, B., Kuo, Y. H., and Zou, X.: Analysis and validation of GPS/MET data in the neutral atmosphere, J. Geophys. Res., 102, 29849-29866, doi:10.1029/97JD02400, 1997.

Roeckner, E., Bäuml, G., Bonaventura, L., Brokopf, R., Esch, M., Giorgetta, M., Hagemann, S., Kirchner, I., Kornblueh, L., Manzini, E., Rhodin, A., Schlese, U., Schulzweida, U., and Tompkins, A.: The atmospheric general circulaton model ECHAM5, Tech. Rep. 349, Max-Planck-Institute for Meteorology, Hamburg, 2003.

Roeckner, E., Jungclaus, J., Mikolajewicz, U., and Hagemann, S.: Model Information of Potential Use to the IPCC Lead Authors and the AR4: ECHAM5/MPI-OM, 2005.

Salby, M. L.: Fundamentals of atmospheric physics, vol. 61 of International geophysics series, Acad. Press, San Diego, Calif., 2006.
Santer, B. D., Wigley, T. M. L., Boyle, J. S., Gaffen, D. J., Hnilo, J. J., Nychka, D., Parker, D. E., and Taylor, K. E.: Statistical significance of trends and trend differences in layer-average atmospheric temperature time series, J. Geophys. Res., 105, 73377356, doi:10.1029/1999JD901105, 2000.

Santer, B. D., Wigley, T. M. L., Simmons, A. J., Kållberg, P. W., Kelly, G. A., Uppala, S. M., Ammann, C., Boyle, J. S., Brüggemann, W., Doutriaux, C., Fiorino, M., Mears, C., Meehl, G. A., Sausen, R., Taylor, K. E., Washington, W. M., Wehner, M. F., and Wentz, F. J.: Identification of anthropogenic climate change using a second-generation reanalysis, J. Geophys. Res., 109, D21104, doi:10.1029/2004JD005075, 2004.

Santer, B. D., Thorne, P. W., Haimberger, L., Taylor, K. E., Wigley, T. M. L., Lanzante, J. R., Solomon, S., Free, M., Gleckler, P. J., Jones, P. D., Karl, T. R., Klein, S. A., Mears, C., Nychka, D., Schmidt, G. A., Sherwood, S. C., and Wentz, F. J.: Consistency of modelled and observed temperature trends in the tropical troposphere, Int. J. Climatol., 28, 1703-1722, doi:10.1002/joc.1756, 2008.

Scherllin-Pirscher, B., Kirchengast, G., Steiner, A. K., Kuo, Y.H., and Foelsche, U.: Quantifying uncertainty in climatological fields from GPS radio occultation: an empirical-analytical error model, Atmos. Meas. Tech., 4, 2019-2034, doi:10.5194/amt-42019-2011, 2011.

Schmidt, T., Wickert, J., and Haser, A.: Variability of the upper troposphere and lower stratosphere observed with GPS radio occultation bending angles and temperatures: GNSS Remote Sensing1, Adv. Space Res., 46, 150-161, doi:10.1016/j.asr.2010.01.021, 2010.

Simmons, A. and Gibson, J. K.: The ERA-40 Project Plan, vol. 1 of ERA-40 Project Report Series, European Centre for Medium Range Weather Forecasts, Reading, UK, 2000.

Simmons, A., Uppala, S. M., and Dee, D.: Update on ERA-Interim, ECMWF Newsletter 111, 2007a.

Simmons, A., Uppala, S. M., Dee, D., and Kobayashi, S.: ERAInterim: New ECMWF reanalysis products from 1989 onwards, ECMWF Newsletter 110, 2007b.

Smith, E. K. and Weintraub, S.: The constants in the equation for atmospheric refractive index at radio frequencies, Proceedings of the I.R.E., 41, 1035-1037, 1953.

Steiner, A. K., Kirchengast, G., and Ladreiter, H. P.: Inversion, error analysis, and validation of GPS/MET occultation data, Ann. Geophys., 17, 122-138, doi:10.1007/s00585-999-0122-5, 1999.

Steiner, A. K., Kirchengast, G., Lackner, B. C., Pirscher, B., Borsche, M., and Foelsche, U.: Atmospheric temperature change detection with GPS radio occultation 1995 to 2008, Geophys. Res. Lett., 36, L18702, doi:10.1029/2009GL039777, 2009.

Steiner, A. K., Lackner, B. C., Ladstädter, F., Scherllin-Pirscher, B., Foelsche, U., and Kirchengast, G.: GPS radio occultation for climate monitoring and change detection, Radio Sci., 46, RSOD24, doi:10.1029/2010RS004614, 2011.

Thorne, P. W., Parker, D. E., Christy, J. R., and Mears, C. A.: Uncertainties in climate trends: lessons from upper-air temperature records, B. Am. Meteorol. Soc., 86, 1437-1442, doi:10.1175/BAMS-86-10-1437, 2005.

Uppala, S. M., Kållberg, P. W., Simmons, A., Andrae, U., Bechtold, V. D. C., Fiorino, M., Gibson, J. K., Haseler, J., Hernandez, A., Kelly, G. A., Li, X., Onogi, K., Saarinen, S., Sokka, N., Allan, R. P., Andersson, E., Arpe, K., Balmaseda, M. A., Beljaars, 
A. C. M., Berg, L. V. D., Bidlot, J., Bormann, N., Caires, S., Chevallier, F., Dethof, A., Dragosavac, M., Fisher, M., Fuentes, M., Hagemann, S., Hólm, E., Hoskins, B. J., Isaksen, L., Janssen, P. A. E. M., Jenne, R., Mcnally, A. P., Mahfouf, J. F., Morcrette, J. J., Rayner, N. A., Saunders, R. W., Simon, P., Sterl, A., Trenberth, K. E., Untch, A., Vasiljevic, D., Viterbo, P., and Woollen, J.: The ERA-40 re-analysis, Q. J. Roy. Meteorol. Soc., 131, 2961-3012, doi:10.1256/qj.04.176, 2005.

Uppala, S. M., Dee, D., Kobayashi, S., Berrisford, P., and Simmons, A.: Towards a climate data assimilation system: status update of ERA-Interim, ECMWF Newsletter 115, 2008.

Vedel, H. and Stendel, M.: On the direct use of GNSS refractivity measurements for climate monitoring, in: Proceedings from the 4th Oersted International Science Team Conference (OIST4), edited by: Stauning, P., pp. 275-278, Danish Meteorological Institute, 2003.

Ware, R., Exner, M., Feng, D., Gorbunov, M., Hardy, K., Herman, B., Kuo, Y., Meehan, T., Melbourne, W., Rocken, C., Schreiner, W., Sokolovskiy, S., Solheim, F., Zou, X., Anthes, R., Businger, S., and Trenberth, K.: GPS Sounding of the atmosphere from Low Earth Orbit: Preliminary results, B. Am. Meteorol. Soc., 77, 19-40, doi:10.1175/15200477(1996)077<0019:GSOTAF>2.0.CO;2, 1996.
Wickert, J., Reigber, C., Beyerle, G., König, R., Marquardt, C., Schmidt, T., Grunwaldt, L., Galas, R., Meehan, T. K., Melbourne, W. G., and Hocke, K.: Atmospheric sounding by GPS radio occultation: First results from CHAMP, Geophys. Res. Lett., 28, 3263-3266, doi:10.1029/2001GL013117, 2001.

Wickert, J., Schmidt, T., Beyerle, G., König, R., Reigber, C., and Jakowski, N.: The radio occultation experiment aboard CHAMP: Operational data analysis and validation of vertical atmospheric profiles, J. Meteorol. Soc. Jpn., 82, 381-395, 2004.

Wickert, J., Beyerle, G., Knig, R., Heise, S., Grunwaldt, L., Michalak, G., Reigber, Ch., and Schmidt, T.: GPS radio occultation with CHAMP and GRACE: A first look at a new and promising satellite configuration for global atmospheric sounding, Ann. Geophys., 23, 653-658, doi:10.5194/angeo-23-653-2005, 2005.

Wilks, D. S.: Statistical methods in the atmospheric sciences, Academic Press Inc., Burlington, San Diego, London, 2nd edn., 2006. 